Article

\title{
Economic Development and Mountain Tourism Research from 2010 to 2020: Bibliometric Analysis and Science Mapping Approach
}

\author{
Liyun Zeng ${ }^{1,2, *}$, Rita Yi Man Li ${ }^{3}{ }^{\oplus}$, Jotikasthira Nuttapong ${ }^{1}$, Jinkun Sun ${ }^{1,2}$ and Yunyi Mao ${ }^{2}$ \\ 1 Rattanakosin International College of Creative Entrepreneurship, Rajamangala University of Technology \\ Rattanakosin, Bangkok 10700, Thailand; jotikasthira@gmail.com (J.N.); paxf66290838@163.com (J.S.) \\ 2 Civil and Architectural Engineering Institute, Panzhihua University, Panzhihua 617000, China; \\ ffengyunsy@163.com \\ 3 Sustainable Real Estate Research Center, Hong Kong Shue Yan University, Hong Kong 999077, China; \\ ymli@hksyu.edu \\ * Correspondence: nonsar@foxmail.com; Tel.: +86-156-0091-2550
}

check for updates

Citation: Zeng, L.; Li, R.Y.M.; Nuttapong, J.; Sun, J.; Mao, Y. Economic Development and Mountain Tourism Research from 2010 to 2020: Bibliometric Analysis and Science Mapping Approach. Sustainability 2022, 14, 562. https:// doi.org/10.3390/su14010562

Academic Editors: Alejandro Vega-Muñoz, Orlando Llanos

Contreras, Miguel Angel García-Gordillo, Jesús Morenas Martín and José Carmelo Adsuar Sala

Received: 30 November 2021 Accepted: 29 December 2021 Published: 5 January 2022

Publisher's Note: MDPI stays neutral with regard to jurisdictional claims in published maps and institutional affiliations.

Copyright: (C) 2022 by the authors. Licensee MDPI, Basel, Switzerland. This article is an open access article distributed under the terms and conditions of the Creative Commons Attribution (CC BY) license (https:/ / creativecommons.org/licenses/by/ $4.0 /)$.

\begin{abstract}
Due to hectic city lives and the growing health concerns in light of the global pandemic, mountain tourism has become increasingly popular worldwide, which has increased the related research. Based on traditional bibliometric laws, such as those authored by Price, Bradford, Lotka, and Zipf, this study acquired 1413 mountain tourism journal articles via bibliometric analysis and identified the most influential journal articles, researchers, and countries in mountain tourism research as indexed in the Web of Science (WoS) database during 2010-2020. The keyword analysis revealed mountain tourism's emerging research topics, including climate change, sustainable development, sustainability, sustainable tourism, protected areas, rural tourism, and conservation. The most influential journal was Sustainability in the mountain tourism. The research results showed that China, the U.S., and Romania produced the most significant mountain tourism articles indexed in the WoS. Most developed countries in Europe had the highest average and average normalized citations, which indicated that they may have more influence in this field as compared to other countries. Some developing countries, such as India, Nepal, and China, had higher citations, average citations, and/or average normalized citations than other countries. The main research trend was the sustainable development aspect of mountain-based tourism during the COVID-19 pandemic. We identified the research gap in WoS; although there is some research shedding light on tourism via bibliometrics, mountain tourism bibliometric analysis and science mapping via VOSViewer is scarce. The paper summarizes the critical aspects of the current discussion of sustainable mountain tourism, such as transport and coopetition (i.e., combing with cooperation and competition) in mountain tourism areas. The results indicated that government agencies and destination managers need to strike a balance between sustainable mountain tourism development and environment and natural landscape conservation after COVID-19.
\end{abstract}

Keywords: mountain tourism; sustainable development; science mapping; scientometric analysis; bibliometric analysis

\section{Introduction}

\subsection{Ecological, Cultural, and Economic Characteristic of Mountain Tourism}

The United Nations Word Tourism Organization (UNWTO) (https: / / www.unwto.org / news/new-covid-19-surges-keep-travel-restrictions-in-place, accessed on 19 December 2021) has indicated that one out of five destinations continues to have their borders closed as new surges of COVID-19 impact the restart of international tourism. Therefore, mountain tourism has become a pertinent topic, considering the travel restrictions to the flatlands during the ongoing COVID-19 pandemic [1]. Mountain tourism challenge to the tourism 
industry due to tourists' behavior and preferences [2]. It refers to tourist activities in mountainous environments characterized by distinct elements of the landscape, climate, wildlife, types of activities, traditions, and local communities [2,3]. Mountain-related attributes and socio- cultural environment enhance mountain tourism's attractiveness to prospective tourists $[4,5]$. The unique natural environment of mountains [6], fresh air [7], and landscapes [8] motivate tourists to "get closer to nature" and seek health-conscious tourist destinations [9]. The religious and cultural traditions of mountain-based communities, the precipitous peaks and snowy terrain make these locations ideal for mountaineering and skiing [10]. Tourism professionals create and market their products by combining activities designed to suit the destination attributes along with other auxiliary services [11]. According to UNWTO (https:/ / www.unwto.org/mountain-tourism, accessed on 19 December 2021), mountain tourism encompasses a broad range of outdoor leisure and sports activities. These economic activities vary in terms of the availability period, location, focused destination attributes, physical fitness demands, and travel length and requirements [11,12], and they can provide significant benefits for local communities, managers, and governments.

\subsection{Mountain Tourism as a Safe and Health Activity}

Mountain tourism may be safer than other forms of tourism because it has the potential to minimize the spread of COVID-19. Complex tourist interests, as well as the variety of natural and cultural resources in remote and often unexplored geographic environments [13], provide a haven in which the pandemic impact has been lessened compared to urban areas. It increasingly attracts wellness tourists. Mountain tourism includes sociocultural tourist activities as well as climbing, trekking, adventuring, cycling [14], sightseeing, touring, or relaxing, among other activities.

Compared to other tourism sectors (e.g., spa tourism, heritage tourism, sightseeing tourism), mountain tourism offers an opportunity for tourists to pursue wellness and related interests. For example, mountain bike tourism is a niche of cycle tourism and is a growing sector in mountain tourism [14], which attracts many wellness tourists seeking both an adventurous and fitness experience during the COVID-19 pandemic. As a result, mountain tourism is sought after by tourists and has gradually become a popular tourist preference. The continued development of mountain tourism has been largely due to these diverse opportunities found in mountainous regions that appeal to a broad range of tourists [13].

\subsection{Increasing Popularity of Mountain Tourism}

According to UNWTO (https: / / www.unwto.org/mountain-tourism, accessed on 19 December 2021), mountain tourism has the potential to stimulate local economic growth and social change due to its complementarity with other economic activities, and its contribution to GDP and job creation as well as its year-round appeal (i.e., its lack of an "off season") provide significant benefits. However, the increasing popularity of mountain tourism can damage the natural environment. Overcrowded destinations as well as tourism professionals that are only interested in economic benefits negatively contribute to destination competitiveness [15]. The competitive market fails to allocate resources efficiently to mitigate these negative factors. Hence, international coordination is necessary to sustain mountain tourism as a savior of the tourism industry during a global pandemic. According to the 2021 Annual Conference of International Mountain Tourism Alliance (http:/ / www.imtaweb.net/ywb/ywsy/, accessed on 22 December 2021), most tourists think that the tourist flow and concentration of mountain tourism areas and the risks are low; travel restrictions and remote office work are not good for the business tourism market, but they provide development opportunities for rural tourism and mountain tourism. In the short to medium term, leveraging the resilience of the international market will be a key driver of tourism recovery.

Mountainous areas account for approximately $27 \%$ of total global land area, and $54 \%$ of the global mountainous area is located in developing countries [16]. According to 
the World Tourism Organization statistics, mountain tourism accounts for approximately $20 \%$ of global tourism and plays an important role in global tourism development [9], especially considering the continuing COVID-19 pandemic. In addition, mountainous areas are important but vulnerable centers of biodiversity [17]. They also have important impacts on global climate change [18]. Since the capacities of mountain ecosystems can be limited [19,20], excessive economic activity such as tourism in mountainous areas has been regulated and limited by governments $[19,21]$. Sustainable mountain tourism has raised much concern regarding its impact on the cultural and natural environments as well as the enforcement of environmental laws [19]. Mountain tourism destinations should consider their responses to the changing market, environmental, and social conditions when expanding and enhancing their offerings [19]. Based on government coordinating research in sustainable tourism, sometimes tourism replaces mining activities in mountain areas. Abandoned mines in mountain areas can not only pose a major environmental hazard but may also bring an end to a local economy [22]. Thus, tourism often coexists with mining in mountain areas under governments' ${ }^{\prime}$ and managers' support. This kind of mountain tourism is also ecologically developed and planned, such as the Jiufen in Taiwan [23] and the Kopaonik Mountain area [22], which also have a high level of natural characteristics and bring economic benefits to local communities [22,23].

\subsection{Research Significance and Structure}

This study assessed the status of international mountain tourism and analyzed the current research focus on mountain-based tourism using a bibliometrics approach. The significance of this study is as follows:

(1) We applied a scientific mapping approach that consisted of a bibliometric literature search and scientometric analysis [24] to minimize the subjectivity and bias in reviewbased studies concerning mountain tourism.

(2) The results indicated that government and industry professionals need to maintain the relationship between sustainable mountain tourism development and environmental conservation. Due to the COVID-19 pandemic, mountain tourist destination management should collaborate with other competitors in the market to develop novel and innovative sustainable methods to maximize their economic benefits that align with ecological conservation and the social values of the local community $[19,20]$.

The remainder of this paper is structured as follows: Section 2 presents the previous research on mountain tourism while Section 3 describes the research method; Section 4 provides the results and findings; Section 5 offers the discussion; and Section 6 presents the conclusion.

\section{Literature Review}

The mainstream research topics of mountain tourism have focused on climate change, sustainable mountain tourism development, rural and landscape attributes. Given the abundance of research on mountain tourism, we chose a focused approach considering the most recent published studies.

\subsection{Climate Change in Mountain Tourism Areas}

Agriculture (42\%), tourism (12\%), hydropower (8\%), and health and safety (4\%) have been the leading sectors affected by hydrological and cryospheric changes [25]. Climate change and tourism have a dynamic relationship, wherein environmental changes impact tourist destinations and tourist travel produces emissions that impact the climate [26]. Thus, the relationship between tourism, including mountain tourism, and climate change has become a prevailing research topic. Palomo reported that negative impacts caused by climate change such as those on food and animal feed, water availability, natural hazards regulation, spirituality and cultural identity, aesthetics, recreation, infrastructure, accessibility, and ecosystem services are a direct threat to the livelihoods and cultures of mountain peoples and mountain tourism [27]. Mountain tourism is closely related 
to changes in the climate, as resorts rely heavily on snow sports activities in winter and glacier tourism in summer $[28,29]$. The impact of climate change on mountain tourism has been seen in the following aspects: (1) climate change can lead to a variety of extreme weather conditions such as reduced snowfall, the retreat of glaciers, freezing conditions, heavy rainfall, increased temperatures, and a reduction in overall precipitation [27,30]. For example, in the European Alps, the Hindu Kush Himalayas, and the tropical Andes, many of these changes in snowfall and glaciers have been reported [31]. (2) Climate change also leads to declining snow cover, melting glaciers, and thawing permafrost, which negatively impact recreational activities and winter sports such as glacier viewing, mountaineering, skiing, snowboarding, and cross-country skiing [18,30]. (3) With climate change, the risk of new infections due to melting glaciers in the mountains may be increased. According to Zhong et al. (2020), there are various microorganisms in glaciers, such as "Glacier ice archives fifteen-thousand-year-old viruses", but related viruses and their effects on glacier microbial communities have not been explored [32].

Many researchers have recognized that climate change has become a serious threat to mountain tourism [33], and the very activities it promotes can contribute to the environmental harm in mountainous regions. Probstl-Haider et al. reported that climate change may lead to extended seasons, an advantage for tourist destinations [34]. However, climate-induced phenomena strongly impact mountain tourism activities, such as mountaineering, hiking, biking, swimming, fishing, and golf, as well as water and air sports [34]. The mountain ecosystem is fragile, and species diversity and social development are affected by climate change [35]. In Kashmir Himalaya, Dar et al. studied the high-altitude temperature trends that were increasing and may result in snowmelt, which would pose a severe threat to the local and global climate as well as impact the sustainability of winter tourism in the region [30]. Wang and Qin's research showed that most of the local residents in the Mount Yulong Snow regions believed that climate change had seriously affected the economy, lifestyle, and spiritual world of mountain tourism [36]. Mountainous regions at lower altitudes in Europe have experienced rapid climate changes that influence socialecological systems [37]. Wolfle and et al. indicated that lower-altitude mountain ranges could be attractive winter destinations if they adapted their tourism products to promote environmental responsibility and appeal to prospective tourist desires [38].

From the perspective of conservation, overpopulated locales exceed the sustainable capacity of the ecological environment [18]. According to the 2020 Intergovernmental Panel on Climate Change (IPCC) report, the increased exposure of humans and infrastructure to geological hazards was attributed to increasing populations, tourism, and socioeconomic development, which have decreased the stability and integrity of the natural landscape features such as mountain slopes. Within the context of environmental hazards in the Himalayas, the key driver of climate change has been commercialization. Other factors have included the increased mobility and access of tourists who may be unaware of or ill-prepared to cope with hazards as well as a lack of regulations concerning overcrowding, safety, and building codes [39].

Thimm et al. (2019) presented adaptation strategies as alternatives for snow tourism, such as the implementation of hiking hostels, since climate change will make winter tourist activities in the Black Forest impossible in the long run [40]. Vij et al. (2021) suggested that main adaptation methods could involve wetland protection, the adaptation of planting and cultivation cycles, tree species management, and snowmaking techniques [37]. From the perspective of Salim et al. (2021), a strategy involving the installation of safety equipment, the renovation of access points, or the development of new structures was reactive. However, the adoption of new specializations for workers was a transformative strategy [29]. Willibald et al. (2021) showed that technical snow production was an appropriate adaptation strategy to counter the risks of climate change and internal climate variability. It drastically reduces the uncertainties related to internal climate variability [41]. 


\subsection{Sustainable Mountain Tourism Development}

In terms of the COVID-19 pandemic, the crisis highlights the need for local communities that rely on mountain-based tourism to enhance their resilience and sustainability to the risks simultaneously generated by the pandemic and the accelerating impacts of climate change [42]. Millicevic et al. (2021) reported that sustainable tourism emerged as a logical outcome of preventing the uncontrolled and excessive use of mountain tourism resources and attractions in Sumadija and Western Serbia [43]. The Tourism Sustainability Group (2007) suggested that sustainable tourism should embrace "concerns for environmental protection, social equity, and the quality of life, cultural diversity, and a dynamic, viable economy delivering jobs and prosperity for all" (p. 2). Dornier and Mauri (2018) indicated that a "sharing economy", "marketing perspectives", "sustainability and transportation", and "the institutional, legal, and socioeconomic aspects" of sustainability are four key points that contribute to mountain tourism [44]. The market has to allocate and use resources efficiently under the ecosystem conservation regulated by governments when mountainous regions become popular tourist destinations. Therefore, the ecological, social, and economic aspects have to be considered [45].

Mountains are invaluable ecologically and recreationally and, therefore, need to be managed sustainably [46]. Sustainable economic development, ecological sustainability, and environmental protection are essential for the development of mountain-based tourism and its potential benefits to the local population, such as improvements to infrastructure for access and communication and the creation of jobs and businesses [47]. A participatory approach to mountain tourism planning is vital. It should be conducted in consultation with local, key stakeholders to monitor the ecological effects, such as waste disposal and wildlife conservation, and social indicators, such as affordable housing, fair wages, and employment levels [48]. In terms of local tourism income and employment opportunities, local investment in local tourism is essential to ensure the long-term sustainability of mountain tourism [2]. However, in the interests of sustainability, mountain communities should look beyond supply and demand issues and consider how tourism can be managed effectively [49]. The management of recreational land use and related resources requires a long-term plan, especially if these resources, similar to the mountains themselves, are to be protected. Tourism is not a panacea to the poverty found in some mountainous regions, but tourism planning and development should be carried out according to sustainable tenets to improve life for local residents [50]. Mutana and Mukwada (2017) concluded their report with general appreciation for tourism sustainability among tourism professionals and enterprises, although shortcomings were evident in both the environmental and socioeconomic indicators [51]. When evaluating research opportunities concerning sustainable mountain tourism, Havlikova et al. (2019) found significant issues to consider, including excessive and inappropriate infrastructure and housing as well as insufficient legislation and environmental education [52]. Therefore, Duglio et al.(2019) suggested that tourism professionals and agencies should consider three aspects of their promotion: local food and product marketing, territorial cross-promotion, and collaboration among destination managers to develop integrated tourism packages and activities [53].

\subsection{Mountain Tourism in Rural Areas}

Dax et al. (2019) suggested that current estimations report approximately 380,000 rural villages in China being abandoned in 2000-2016, particularly in its mountainous regions where local initiatives focused on migration and economic concerns were insufficient [54]. Ernawati et al. (2018) concluded that tourism could be a solution for the misuse of the natural environment in mountainous regions by promoting sociocultural and economic benefits in the Pohsanten and Bistra communities, such as improving the quality of accommodation facilities as well as the quality of additional rural tourism opportunities [55]. In a case study of the Valbona Valley National Park, Kortoci (2017) indicated that mountain tourism in rural areas may promote the protection of the natural, social, and cultural environments [56]. 
Considering the COVID-19 pandemic, Linca and Toma (2021) indicated that an increasing number of tourists were choosing rural mountain tourism destinations to rent private villas, mountain huts, apartments, or holiday homes for the purpose of social distancing [57]. Rural regions with agricultural, ecocultural, and cultural tourism destinations provide the opportunity to enjoy closer contact with nature and untouched landscapes [58]. Rural tourism has grown, and the demand for products and experiences has gradually expanded, especially as an alternative source of employment in mountainous regions [59]. The unique resources allow tourists to enjoy the scenery and delicious food, to purchase locally produced products, and to experience the life and activities; these resources also give tourists the cornerstone of a free experience [58]. Most tourists have been choosing mountain tourism in rural areas over suburban rural tourism, and mountainous areas that exist just outside suburban areas have gained in popularity [55]. With the acceleration of urbanization in various places, the industrial atmosphere in the suburbs has dramatically increased [55]. The natural environment and organic food found just outside suburban areas have become great attractions for tourists just as mountain tourism destinations far from the urban environment have also increased in demand [55]. Using spatial and statistical analysis and field surveys, Savulescu et al. (2019) confirmed that mountain tourism changed the traditional agricultural landscape by generating potential environmental conflicts that thereby indicated the sustainability impact on the Romanian Carpathians [60].

Although rural mountain tourism has many advantages, including the development of suburban rural tourism, many problems inevitably appear that slow its development [61]. Case studies of mountainous regions in Germany, Italy, Romania, Ukraine, and Poland have shown that mountain tourism may act as an essential driver for rural development in peripheral mountain communities that often face serious economic, social, and environmental challenges [62]. Therefore, retail trade, transportation, and communication strategies should focus on more effectively conserving natural and cultural resources, and, with increased employment opportunities in developing mountain tourism destinations, a sufficient local, employable population is crucial [63].

\subsection{Landscape Attributor for Mountain Tourism}

In the tourism industry, the resources are the destinations, in which the "raw material" is the natural landscape [64]. As for mountain tourism characteristics, landscape aesthetics and features attract tourists and "amenity migrants", or those interested in relocating primarily for improved quality of life [65]. The balance of aesthetics and diversity of activities is vital when planning mountain tourism products so as to prevent exceeding a destination's carrying capacity. The superior aesthetic qualities of a mountainous landscape attract the young and vigorous, the adventurous, the spiritually exhausted, and potential amenity migrants. Therefore, conserving and improving the exceptional aesthetic qualities of the natural landscape is a customary concern of tourism planning.

The contextual sociocultural experience in mountain-based tourism destinations can include symbolic landscape features that attract tourists [66], such as ambient conditions, spatial layout, and functionality as well as signs, symbols, and artifacts. Mountain-based tourism drivers convert the natural landscape into tourist destinations where hot springs, huts, facilities, convenient transportation, hotels, and broader walkways attract tourists [31]. The characteristic project created by mountain tourism involves the mountainous landscape [67]. In Japan's mountain tourism, Chakraborty suggested that these landscapes were under renewed threat, such as the depletion of natural ecosystems, a trivialization of place, and increased pollution caused by visitors and global environmental change [68]. Zheng provided a reliable basis to monitor the green development of the ecological environment surrounding popular scenic spots due to the impact of pollution on the ecosystems of natural, mountainous landscapes [69]. 


\section{Bibliometrics and the Science-Mapping Research Method}

Mountain tourism research employs various methodologies, such as interviews [70], questionnaire-based surveys [55], case studies [71], computer simulations (e.g., Web GIS, GNSS) [72], field surveys [73], data analyses [74], descriptive statistical analyses [75], model analyses [76], index analyses [77], regression analyses [61], cluster analyses [78], and other experimental approaches [79]. There is also some research shedding light on tourism bibliometrics, such as coastal tourism [80], rural tourism [81], eco-tourism [82], etc. Although María and et al. (2018) studied mountain tourism bibliometrics [6], they did not combine it with a science mapping approach. However, science mapping and bibliometrics have rarely been used in the relevant literature of mountain tourism.

Professor Hall (2006) raised concerns over "the use of bibliometric tools for purposes for which they were not originally designed" [83]. He noted that "tourism studies have recently been subject to increasing debate regarding journal and research rankings. This debate is reflective of broader concerns over the use of bibliometric tools for purposes for which they were not originally designed" [83]. Therefore, he used Google Scholar citations as an alternative means of accessing the citation impact of tourism publications in comparison with the Clarivate (formerly Thomson Reuters) Institute of Scientific Information (ISI) databases. However, Google Scholar results include only those sources that are available on the Internet, whereas ISI includes journals that do not yet have digital versions [83]. Clarivate Analytics's Web of Science (WoS) is the world's leading scientific citation search and analytical information platform, which supports a broad array of scientific tasks across diverse knowledge domains and a dataset for large-scale data-intensive studies [84]. Some researchers, such as Li et al. (2021), have employed a scientometric review of tourism research from WoS's core collection database from 2001-2020 [85].None of these threw light on mountain tourism, though. Thus, in this study, we used the WoS database. We evaluated the latest research in mountain tourism published during 2010-2020 in the WoS database using the science mapping approach that consisted of a bibliometric search and a scientometric analysis. Scientometric analysis can quantitatively measure documented events similarly to the evaluation of economic activities using bibliometric laws and indicators [86].

\subsection{Bibliometrics}

The bibliometric search of mountain tourism publications was performed using the WoS. We used keywords to refine the results of searches performed in the WoS Core Collection: "mountain tourism" or "mountain-based tourism", for example. Using this tool, we could search all authors and author affiliates.We used the citation report function to track and identify citation activity and trends; finally, we analyzed the search results to determine research trends and publication patterns. Thus, we obtained information including the publication year, journal, etc., to analyze trends and characteristics [9] based on methods used in prior research.

Previous researchers have applied Price's law to initiate bibliometric analysis, such as the research into global trends in coffee agronomy by Madrid-Casaca et al. (2021) [87]. In the context of Price's law, the square root of all contributors in a subject area produce half of the publications [88].

In order to identify a concentration of journals where authors offered in-depth discussions regarding mountain tourism, Bradford's law was applied [89]. According to Bradford's law, adjustment of the journal concentration zones to a geometric series is possible [90-93]. Bradford's law was employed to estimate and identify the journals with the most frequent publications concerning mountain tourism so the journal concentration zones could be fitted to a geometric series [90-93].

Zipf's law on words was applied to empirically determine words with the highest frequency of occurrence within the set of studied articles [94]. Researchers have applied Zipf's law for keywords analysis [95]. The number and connections of keywords obtained from the titles and the summaries of articles can indicate possible research hotspots in an academic field [96]. In accordance with Zipf's law, the bibliometric analysis produced a 
topical thematic result from related keywords and refined with "mountain tourism" in the WoS database [94,97].

Applying Lotka's Law, which is based on the unequal distribution of scientific publication among authors [98], our research established and estimated the principal WoS category and its temporal trends, the prolific authors $[99,100]$, and the level of co-authorship between authors and their collaborators [101,102], using VOSviewer and Pajek [88,103]. When analyzing researchers and their cooperation network, the node's size represented the number of articles posted by the author, and the number and thickness of lines represented the collaborative relationship and its intensity. Analyzing the number of posts issued from various countries can suggest the dominant countries studying mountain tourism [104].

\subsection{Science Mapping}

Scientometric analysis was an instrument used in the social sciences during a period of accelerated scientific progress where large-scale, government-funded projects were launched to achieve global scientific leadership [86]. VOSViewer, a text-mining tool developed by Van Eck and Waltman (2010), was adopted in this study for analyzing and visualizing bibliometric networks. VOSViewer provided distance-based visualizations of the bibliometric network; the distance separating two nodes approximately indicates the relation between them [103]. VOSViewer is suitable for visualizing more extensive networks with special text-mining features. Some research studies have adopted VOSViewer to assist with literature reviews of various topics, such as climate change, sustainability, protected areas, landscapes, etc. The present study adopted VOSViewer to (1) load the downloaded literature from WoS; (2) visualize, compute, and analyze the influence of journals, scholars, publications, and countries in mountain tourism research; and (3) study common research keywords and their inter-relationships.

\section{Results of Scientometric Analysis}

\subsection{An Overview of the Literature Review}

The keyword-based bibliometric search of the WoS included 1413 mountain tourism articles. Figure 1 shows the number of papers published annually during 2010-2020. Excluding the incomplete data in 2020, the annual number of publications had increased from less than 100 total articles in 2010 to over 140 in 2015. This indicated that research interest in mountain tourism had increased in recent years.

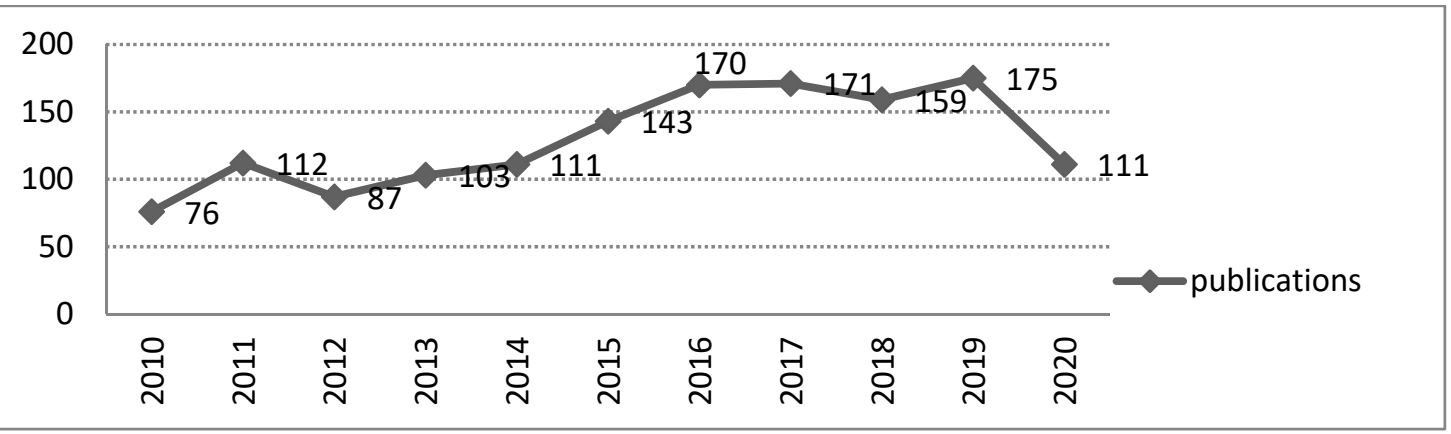

Figure 1. Yearly publications during 2010-2020.

\subsection{Science Mapping of Published Sources}

The minimum number of documents and the minimum number of citations were set at 10 and 80, respectively, in VOSViewer. A total of 11 out of the 719 journals met the threshold. Figure 2 presents the clusters of research sources and their inter-relationships. Applying Bradford's law, the scientometric analysis identified a core of 11 journals (Figure 2) where the academic debate and discussion regarding mountain tourism was the focus. In Figure 2, the font and node size visually represent the number of publications from the given journals, with larger font and node sizes indicating a higher number of publications [5]. The clusters 
represented by different colors and connection lines indicate the closeness among journals in terms of mutual citations. Citations have been used as a measurement of a scholarly work's influence in a domain [103]. Table 1 lists the number of documents, the average and the total number of citations, and the average number of normalized journals. The results quantified the impact of the journals in mountain tourism. The top three journals with the most prominent mountain tourism publications were Sustainability, the Journal of Mountain Science, and Mountain Research and Development. These publications have been considered authoritative sources of tourism research, and the search results suggested a developing trend of mountain tourism research.

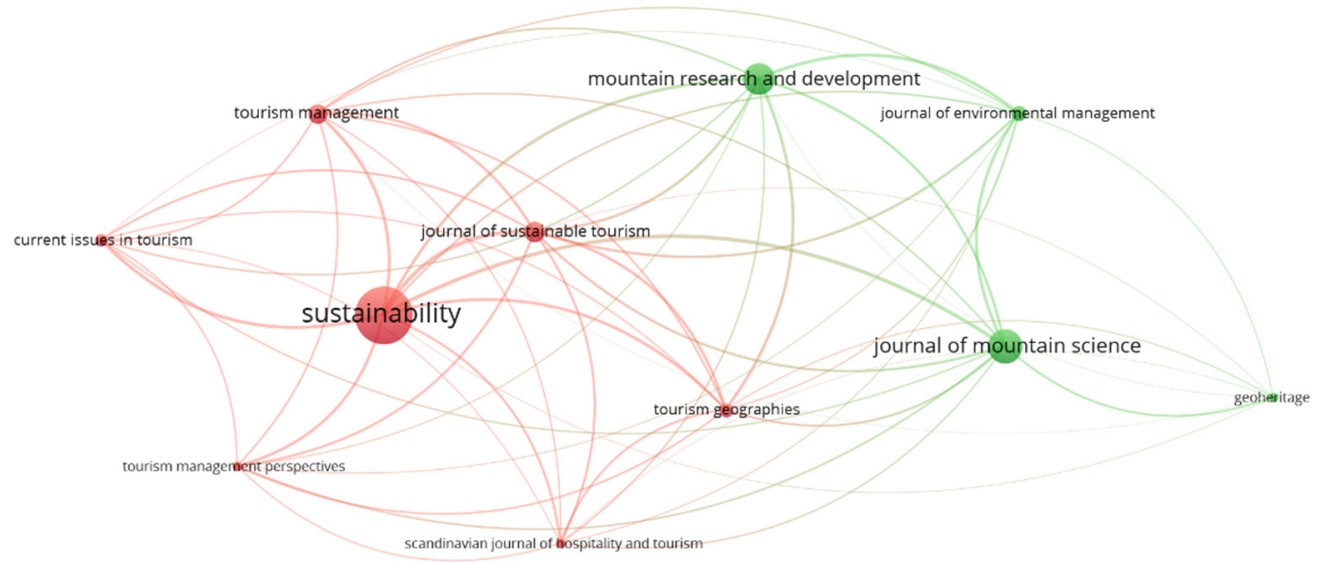

Figure 2. Mapping of mainstream journals in the domain of mountain tourism.

Table 1. Quantitative measurements of publications of mountain tourism research.

\begin{tabular}{|c|c|c|c|c|c|}
\hline Country & $\begin{array}{l}\text { Number of } \\
\text { Documents }\end{array}$ & $\begin{array}{c}\text { Number of } \\
\text { Citations }\end{array}$ & $\begin{array}{c}\text { Average } \\
\text { Publication Year }\end{array}$ & $\begin{array}{l}\text { Average } \\
\text { Citation }\end{array}$ & $\begin{array}{l}\text { Avg. Norm. } \\
\text { Citation }\end{array}$ \\
\hline Sustainability & 59 & 236 & 2018 & 4 & 1.221 \\
\hline Journal of Mountain Science & 35 & 121 & 2017 & 3.4571 & 0.7382 \\
\hline $\begin{array}{c}\text { Mountain Research and } \\
\text { Development }\end{array}$ & 32 & 489 & 2014 & 15.2812 & 1.565 \\
\hline Journal of Sustainable Tourism & 21 & 300 & 2016 & 14.2857 & 2.2101 \\
\hline Tourism Management & 20 & 405 & 2016 & 20.25 & 2.8559 \\
\hline $\begin{array}{c}\text { Journal of Environmental } \\
\text { Management }\end{array}$ & 16 & 560 & 2015 & 35 & 3.462 \\
\hline Tourism geographies & 15 & 144 & 2017 & 9.6 & 1.4735 \\
\hline Current Issues in Tourism & 13 & 82 & 2015 & 6.3077 & 1.8304 \\
\hline Geoheritage & 11 & 118 & 2017 & 10.7273 & 1.8142 \\
\hline $\begin{array}{l}\text { Scandinavian Journal of } \\
\text { Hospitality and Tourism }\end{array}$ & 11 & 123 & 2014 & 11.1818 & 1.1132 \\
\hline $\begin{array}{c}\text { Tourism Management } \\
\text { Perspectives }\end{array}$ & 10 & 101 & 2017 & & \\
\hline
\end{tabular}

Figure 2 and Table 1 present the most productive journals, namely Sustainability and the Journal of Mountain Science, although these journals had the lowest average number of citations. Tourism Management and the Journal of Environmental Management had the highest average number of citations. Table 1 displays journal citation data.

\subsection{Co-Occurrence of Keywords}

Keywords represent the main content of the research topics [105]. They can be analyzed systematically to provide future directions for research [106]. Therefore, keywords of articles published over the last decade were analyzed using VOSViewer.

A network of keywords displayed the relationships and the organization of research themes, following the method used by Van Eck and Waltman (2014). In addition, following 
the recommendations of Jin et al. (2019), we used "author keywords" and "fractional counting" in the VOSViewer analysis. Applying Zipf's law, the minimum occurrence of a keyword was set at seven. Initially, 65 out of the 4341 keywords met the threshold, from which some general items were then removed, e.g., "mountain tourism", "tourism", "development", "mountainous regions", "mountainous areas", "mountain", and "mountains". Some other keywords with the same semantic meanings, such as "protected areas" versus "protected area", and "national parks" versus "national park", were combined in the second round of the keyword analysis. Finally, a total of 56 keywords were selected, as shown in Figure 3 and Table 2.

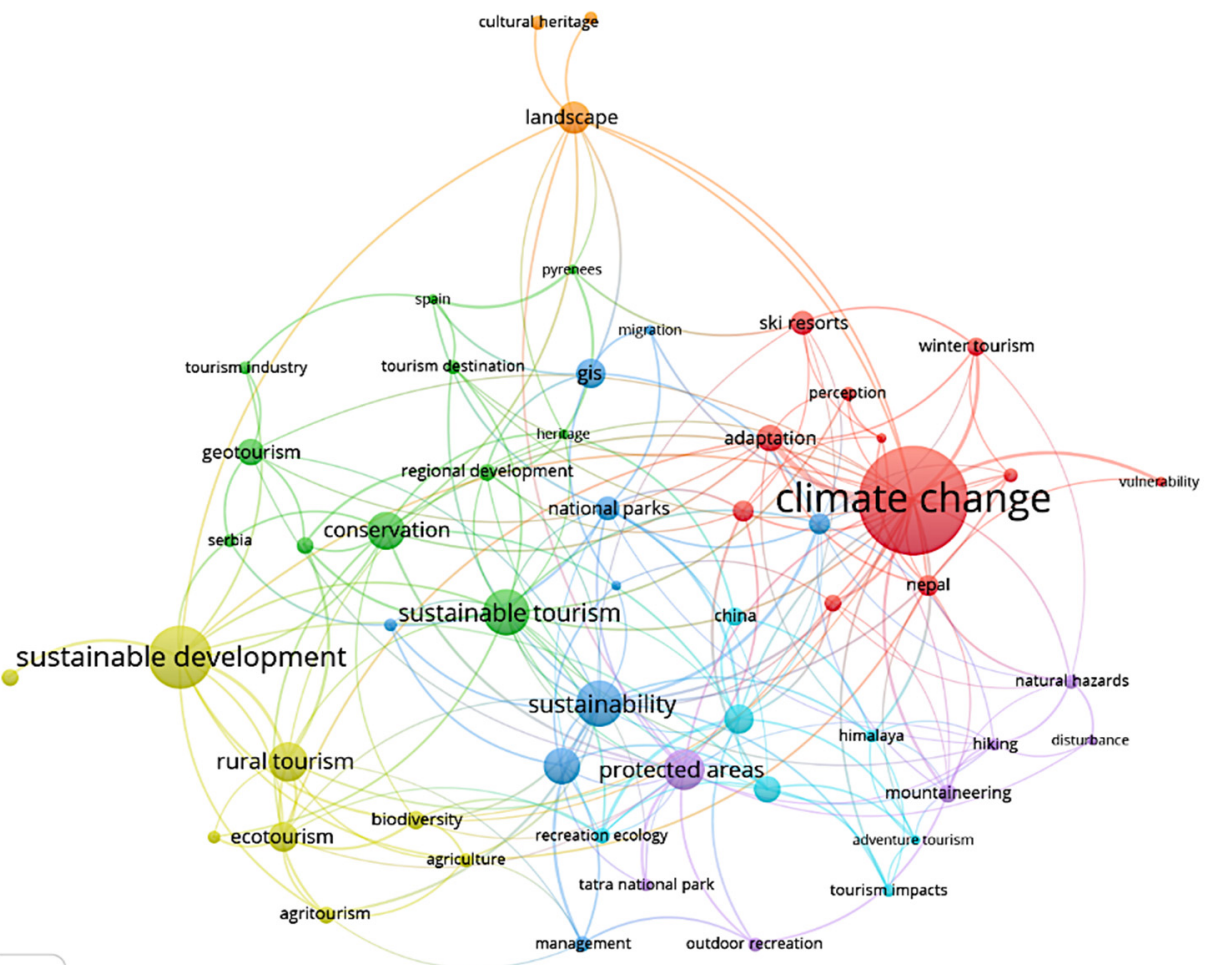

Figure 3. Co-occurrence of keywords in mountain tourism research.

The node sizes, the distances among nodes, and the connection lines among keywords, as visualized in Figure 3, suggested the most frequently studied terms included but were not limited to: climate change, sustainable development, sustainability, sustainable tourism, protected areas, rural tourism, conservation, tourism development, and landscape. The colors of the nodes divided these keywords into different clusters. In Figure 3, the node's size reflects the number of keywords with larger font and node sizes indicating larger numbers of keywords [105]. The connection lines indicated the closeness among the keywords in mountain-based tourism research [5].

As shown in Figure 3, sustainable development, rural tourism, ecotourism, agritourism, and biodiversity were strongly related to each other within the same cluster. Climate change, adoption, perception, ski resorts, winter tourism, Nepal, and vulnerability were strongly related within the same cluster. Keywords from different clusters were also strongly linked, such as sustainability and protected area as well as sustainability and climate change. The most robust links were between sustainability and rural tourism as well as between climate change and Nepal. The most recent literature did not appear to address the link between the tourism industry and disturbance.

Generally, the common research keywords were climate change, sustainable development, sustainability, sustainable tourism, and protected areas. 
Table 2. Summaries of primary keywords in mountain tourism research.

\begin{tabular}{|c|c|c|c|c|}
\hline $\begin{array}{l}\text { Keywords in Mountain } \\
\text { Tourism Research }\end{array}$ & Occurrence & $\begin{array}{c}\text { Average Publication } \\
\text { Year }\end{array}$ & Average Citation & Avg. Norm. Citation \\
\hline Climate change & 69 & 2016 & 12 & 1.6317 \\
\hline Sustainable development & 40 & 2015 & 2.825 & 0.5227 \\
\hline Sustainability & 29 & 2017 & 12.931 & 2.0567 \\
\hline Sustainable tourism & 29 & 2016 & 10.4138 & 1.2991 \\
\hline Protected areas & 26 & 2016 & 8 & 1.2379 \\
\hline Rural tourism & 25 & 2015 & 3.68 & 0.6795 \\
\hline Conservation & 24 & 2016 & 6.8333 & 0.8472 \\
\hline Tourism development & 23 & 2015 & 4.6957 & 0.8368 \\
\hline Landscape & 21 & 2016 & 2.9048 & 0.8229 \\
\hline Ecotourism & 19 & 2015 & 5.5789 & 0.9144 \\
\hline GIS & 19 & 2015 & 5.1579 & 0.7235 \\
\hline Nature-based tourism & 19 & 2014 & 18.4211 & 1.7346 \\
\hline Adaptation & 17 & 2017 & 9.2353 & 2.3745 \\
\hline Geotourism & 17 & 2015 & 10.4706 & 1.3774 \\
\hline Mountain biking & 17 & 2015 & 21.7059 & 2.3091 \\
\hline National parks & 15 & 2016 & 5.2667 & 0.9571 \\
\hline Ski resorts & 15 & 2016 & 3.9333 & 0.7221 \\
\hline Alps & 14 & 2016 & 7.8571 & 1.4638 \\
\hline Nepal & 14 & 2016 & 11.7857 & 1.1724 \\
\hline Recreation & 14 & 2014 & 14.5714 & 1.9272 \\
\hline Biodiversity & 12 & 2014 & 12.3333 & 1.3604 \\
\hline China & 12 & 2017 & 3.4167 & 0.8532 \\
\hline Mountaineering & 12 & 2016 & 7.3333 & 1.414 \\
\hline Winter tourism & 12 & 2013 & 11.6667 & 1.3927 \\
\hline Agritourism & 11 & 2017 & 3.7273 & 1.8328 \\
\hline Ecosystem services & 11 & 2017 & 9.1818 & 2.0999 \\
\hline Regional development & 11 & 2014 & 5.7273 & 0.721 \\
\hline Romania & 11 & 2016 & 2.7273 & 0.4245 \\
\hline Rural development & 11 & 2017 & 1.0909 & 0.4433 \\
\hline Management & 10 & 2016 & 3.8 & 0.5539 \\
\hline Recreation ecology & 10 & 2013 & 36.7 & 3.2407 \\
\hline Agriculture & 9 & 2015 & 3.7778 & 0.3533 \\
\hline Cultural heritage & 9 & 2015 & 0.4444 & 0.049 \\
\hline Natural hazards & 9 & 2015 & 10.5556 & 1.4528 \\
\hline Outdoor recreation & 9 & 2018 & 3.1111 & 0.8315 \\
\hline Perception & 9 & 2015 & 17.1111 & 1.7591 \\
\hline Switzerland & 9 & 2014 & 18.5556 & 1.6058 \\
\hline Tourism destination & 9 & 2017 & 14 & 1.7991 \\
\hline Environment & 8 & 2015 & 3 & 0.4915 \\
\hline Hiking & 8 & 2016 & 23 & 2.4248 \\
\hline Himalaya & 8 & 2016 & 5.375 & 1.0144 \\
\hline Land use & 8 & 2015 & 7.25 & 0.9649 \\
\hline Serbia & 8 & 2016 & 9.5 & 0.823 \\
\hline Tatra national park & 8 & 2017 & 2.5 & 0.5955 \\
\hline Tourism impacts & 8 & 2015 & 10.375 & 1.4415 \\
\hline Tourism industry & 8 & 2015 & 14.5 & 1.3674 \\
\hline Turkey & 8 & 2014 & 10.125 & 1.133 \\
\hline Adventure tourism & 7 & 2015 & 9.7143 & 1.1513 \\
\hline Disturbance & 7 & 2016 & 8 & 0.7085 \\
\hline Forest management & 7 & 2016 & 10.8571 & 1.4669 \\
\hline Heritage & 7 & 2016 & 1 & 0.2122 \\
\hline Migration & 7 & 2015 & 13.4286 & 1.559 \\
\hline Pyrenees & 7 & 2014 & 15.2857 & 1.4808 \\
\hline Spain & 7 & 2017 & 14.1429 & 1.787 \\
\hline
\end{tabular}




\subsection{Co-Authorship Analysis}

The investigation of research collaboration and the co-authorship of publications found that the minimum number of articles published and the minimum number of citations of an author set in VOSViewer were 3 and 30, respectively. A total of 62 out of the 3979 authors from the literature sample met the selection criteria. The most influential authors are presented in Figure 4 and Table 3. As shown in Figure 4, the authors were attributed to three categories that represented their research networks. The cluster size indicated the strength of their research connections.

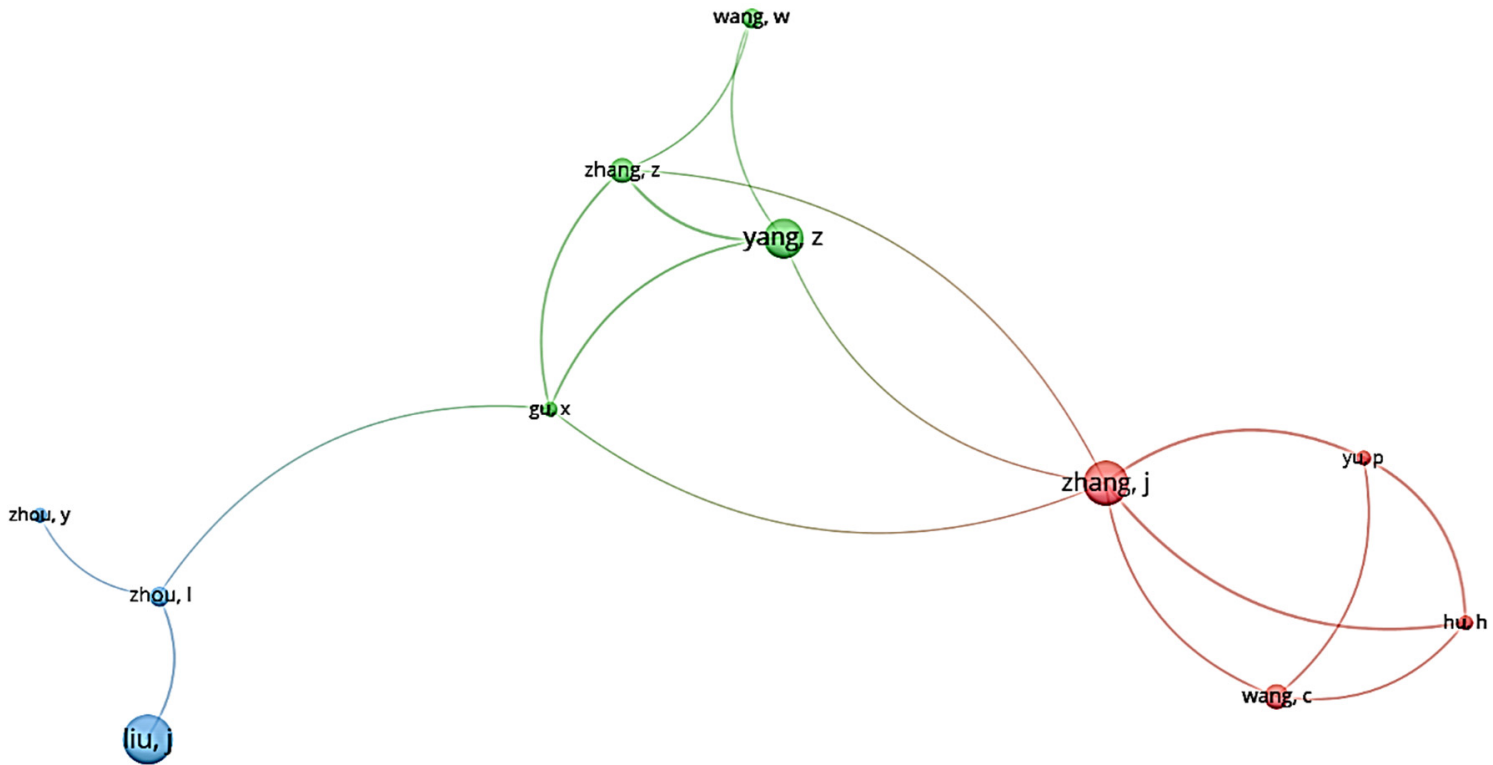

Figure 4. Co-authorship analysis in mountain tourism research.

Table 3. Quantitative measurements of scholars in mountain tourism research.

\begin{tabular}{cccccc}
\hline Scholar & $\begin{array}{c}\text { Number of } \\
\text { Documents }\end{array}$ & $\begin{array}{c}\text { Number of } \\
\text { Citations }\end{array}$ & $\begin{array}{c}\text { Average } \\
\text { Publication } \\
\text { Year }\end{array}$ & $\begin{array}{c}\text { Average } \\
\text { Citation }\end{array}$ & $\begin{array}{c}\text { Avg. Norm. } \\
\text { Citation }\end{array}$ \\
\hline Liu, J. & 10 & 99 & 2017 & 9.9 & 1.1392 \\
Zhang, J. & 9 & 82 & 2018 & 9.1111 & 2.7787 \\
Yang, Z. & 8 & 69 & 2017 & 8.625 & 1.5783 \\
Wang, C. & 5 & 45 & 2018 & 9 & 2.9747 \\
Zhang, Z. & 5 & 58 & 2017 & 11.6 & 1.8092 \\
Wang, W. & 4 & 45 & 2015 & 11.25 & 1.2815 \\
Zhou, L. & 4 & 46 & 2016 & 11.5 & 2.5371 \\
Gu, X. & 3 & 36 & 2015 & 12 & 2.4708 \\
Hu, H. & 3 & 50 & 2018 & 16.6667 & 5.589 \\
Yu, P. & 3 & 50 & 2018 & 16.6667 & 5.589 \\
Zhou, Y. & 3 & 69 & 2014 & 23 & 3.5892 \\
\hline
\end{tabular}

Table 3 presents the five main quantitative measurement methods, namely, the total link strength, the number of published articles, the total number of citations in the WoS, the average publication period, and the average number of citations per article. The first three metrics showed the production of research results and the impact of a given author on the research community [5]. According to Table 3, Liu was the most productive author in the field of mountain tourism research. As compared to the other authors, Liu was cited more frequently, illustrating that Liu was both productive and influential in this field. Other scholars who made significant contributions to the research community include Zhang, Yang, and Zhou. These scholars have also collaborated with one another, as shown in Figure 4. The average publication year indicated emerging researchers, including $\mathrm{Hu}, \mathrm{Yu}$, 
Wang, and Zhang. Their publications were generally published around the year 2018. The standardized citation analysis showed the average annual influence of researchers such as $\mathrm{Hu}$ and $\mathrm{Yu}$. Although they were not the most published, they had a higher average number of citations and the highest annual impact; thus, they have made significant contributions to mountain tourism research.

\subsection{Citation of Articles}

Being cited in other published works represents influence in the research domain. The most influential publications in the last decade were also investigated using VOSViewer. When we set the minimum number of citations at 43, a total of 37 out of 1413 articles were found. The most influential articles measured by the number of citations are shown in Figure 5. Consistent with the findings in Figure 4 and Table 3, the visualization in Figure 5 further illustrated that Steven (2011) led a series of studies that contributed significantly to mountain tourism research. More details concerning these articles, including full titles, number of links, and total citations, are summarized in Table 4.

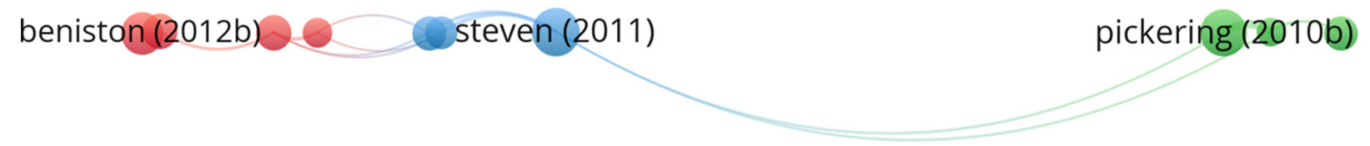

Figure 5. Science mapping of the most influential publications in mountain tourism research.

Table 4. List of publications with the highest impact in mountain tourism research.

\begin{tabular}{|c|c|c|c|c|c|}
\hline Scholar & Title & $\begin{array}{l}\text { Number of } \\
\text { Citations }\end{array}$ & $\begin{array}{l}\text { Average } \\
\text { Publication } \\
\text { Year }\end{array}$ & $\begin{array}{l}\text { Average } \\
\text { Citation }\end{array}$ & $\begin{array}{l}\text { Avg. Norm. } \\
\text { Citation }\end{array}$ \\
\hline Steven (2011) & $\begin{array}{l}\text { A review of the impacts of nature-based } \\
\text { recreation on birds }\end{array}$ & 126 & 2011 & 126 & 9.1577 \\
\hline Pickering (2010b) & $\begin{array}{c}\text { Comparing hiking, mountain biking, and } \\
\text { horse-riding impacts on vegetation and } \\
\text { soils in Australia and the United States of } \\
\text { America }\end{array}$ & 119 & 2010 & 119 & 8.2069 \\
\hline Beniston (2012b) & $\begin{array}{l}\text { Impacts of climatic change on water and } \\
\text { associated economic activities in the } \\
\text { Swiss Alps }\end{array}$ & 99 & 2012 & 99 & 8.7 \\
\hline Rixen (2011) & $\begin{array}{l}\text { Winter tourism and climate change in the } \\
\text { Alps: an assessment of resource } \\
\text { consumption, snow reliability, and future } \\
\text { snowmaking potential }\end{array}$ & 67 & 2011 & 67 & 4.8696 \\
\hline Beniston (2012a) & $\begin{array}{l}\text { Is snow in the Alps receding or } \\
\text { disappearing? }\end{array}$ & 66 & 2012 & 66 & 5.8 \\
\hline Cetin (2016) & $\begin{array}{l}\text { Evaluating the recreation potential of } \\
\text { Ilgaz Mountain National Park in Turkey }\end{array}$ & 64 & 2016 & 64 & 12.3496 \\
\hline Thiel (2011) & $\begin{array}{l}\text { Winter tourism increases stress hormone } \\
\text { levels in the capercaillie Tetrao urogallus }\end{array}$ & 60 & 2011 & 60 & 4.3608 \\
\hline Braunisch (2011) & $\begin{array}{l}\text { Spatially explicit modelling of conflict } \\
\text { zones between wildlife and snow sports: } \\
\text { prioritizing areas for winter refuges }\end{array}$ & 55 & 2011 & 55 & 3.9974 \\
\hline Pickering (2010a) & $\begin{array}{l}\text { Climate response by the ski industry: the } \\
\text { shortcomings of snowmaking for } \\
\text { Australian resorts }\end{array}$ & 49 & 2010 & 49 & 3.3793 \\
\hline Barros (2013) & $\begin{array}{l}\text { Impacts of informal trails on vegetation } \\
\text { and soils in the highest protected area in } \\
\text { the southern hemisphere }\end{array}$ & 44 & 2013 & 44 & 3.4412 \\
\hline
\end{tabular}


The themes of the highly-cited articles included (1) winter tourism resources, activities, and development potential [107-109]; (2) the spatially explicit modelling of tourism destinations; (3) winter tourism increasing stress hormone levels; (4) recreational potential; and (5) vegetation and soil protection [110]. These highly cited articles all concerned sustainable development in mountainous regions. The most cited article in the last decade was from Steven (2011), who studied the impact of natural recreational activities on birds. Pickering (2010b) ranked second in terms of citation rates in the last ten years. Some trends suggested by the present study included those comparing the impact of hiking, mountain biking, and horseback riding on soil and vegetation in Australia and the U.S. Ecology and sustainability were the main research topics. Beniston et al. (2012b) had the third most cited article, which focused on the impact of Swiss climate change on water and related economic activities.

These results affirmed those found in the co-authorship analysis (Figure 4); however, there were few collaborations found in these articles, and it is vital to improve author networks in this research domain.

\subsection{Countries Active in Mountain Research}

VOSViewer was used in this study to further identify and evaluate country-specific contributions to the global research community, and the minimum number of documents and citations per country were set at 15 and 60, respectively. A total of 25 out of 95 countries were identified. Figure 6 and Table 5 present the findings of countries that have been active in mountain tourism research over the last decade.

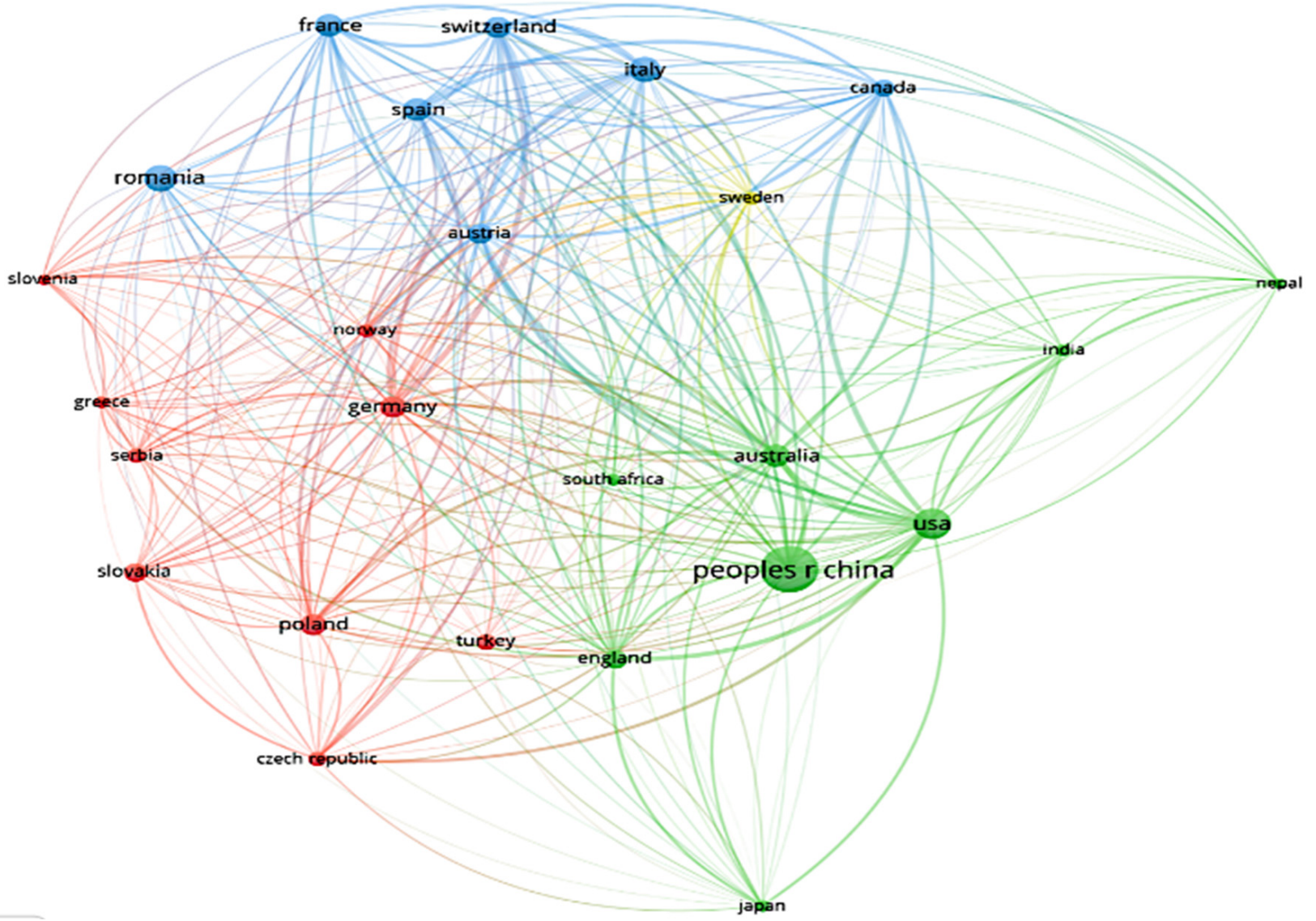

Figure 6. Mapping of countries actively researching mountain tourism. 
Table 5. Number of documents published in 25 countries (from high to low).

\begin{tabular}{|c|c|c|c|c|c|}
\hline Country & $\begin{array}{c}\text { Developing/Developed } \\
\text { Countries }\end{array}$ & Continent & $\begin{array}{l}\text { Weight } \\
\text { (Links) }\end{array}$ & $\begin{array}{l}\text { Weight (Total } \\
\text { Link Strength) }\end{array}$ & $\begin{array}{c}\text { Weight } \\
\text { (Documents) }\end{array}$ \\
\hline China. P. R. & Developing & East Asia & 24 & 7936 & 301 \\
\hline U.S. & Developed & North America & 24 & 12064 & 134 \\
\hline Romania & Developing & South Europe & 24 & 2124 & 104 \\
\hline Italy & Developed & South Europe & 24 & 7803 & 93 \\
\hline Australia & Developed & Oceania & 24 & 10468 & 75 \\
\hline Spain & Developed & South Europe & 24 & 6907 & 69 \\
\hline France & Developed & West Europe & 24 & 5628 & 69 \\
\hline Switzerland & Developed & Central Europe & 24 & 8566 & 64 \\
\hline Poland & Developing & Central Europe & 24 & 3651 & 64 \\
\hline Germany & Developed & Central Europe & 24 & 8039 & 62 \\
\hline Austria & Developed & Central Europe & 24 & 8415 & 60 \\
\hline Slovakia & Developed & Central Europe & 24 & 2068 & 49 \\
\hline U.K. & Developed & West Europe & 24 & 5529 & 47 \\
\hline Canada & Developed & North America & 24 & 6934 & 46 \\
\hline Turkey & Developing & West Asia & 24 & 647 & 37 \\
\hline Serbia & Developing & South Europe & 24 & 1811 & 34 \\
\hline Czech Republic & Developed & Central Europe & 24 & 2501 & 33 \\
\hline Sweden & Developed & North Europe & 24 & 3472 & 28 \\
\hline Norway & Developed & North Europe & 24 & 3076 & 26 \\
\hline Greece & Developing & South Europe & 24 & 1729 & 23 \\
\hline Japan & Developed & East Asia & 24 & 1612 & 21 \\
\hline India & Developing & South Asia & 24 & 1855 & 20 \\
\hline South Africa & Developing & Africa & 24 & 1398 & 20 \\
\hline Slovenia & Developed & South Europe & 24 & 1655 & 18 \\
\hline Nepal & Developing & South Asia & 24 & 1664 & 16 \\
\hline
\end{tabular}

The connecting line in Figure 6 shows the research results cited by different countries/regions, which were further measured by the total link strength, as shown in Table 5 . As shown in Figure 6, the following countries or regions contributed to the research (the research institutions were based on their node size and connection lines with other countries/regions): China, the U.S., Romania, Italy, Australia, France, and Spain.

More developed countries have been actively involved in mountain tourism research. That may be due to the history of mountain tourism, which originated in Europe before expanding into North America and then developing throughout the world. In terms of the number of publications and total citations, researchers from China and the U.S. ranked highest, followed by Australia, Switzerland, Italy, and Romania (Tables 5 and 6).

In terms of average citations, the most developed countries had higher average citations, such as Switzerland, Canada, Australia, the U.K., the U.S., Spain, Germany, Sweden, etc., and most were in Europe, while some developing countries such as Nepal had higher average citations than some developed countries such as the U.S., Spain, and Germany (Table 7). The average normalized citation measure indicated that developed countries or regions including Sweden, Canada, Australia, Nepal, Switzerland, Spain, Austria, Germany, and the U.K. had a higher annual impact on the research community (Table 8). With the exception of Nepal, the most influential countries were developed countries, many of which are in Europe. Nepal, India, and Japan were the top three countries with the highest average normalized citations in Asia. Although Slovenia, Switzerland, the U.S., Norway, Czech Republic, Australia, Canada, and other developed countries had fewer publications as compared to China, a developing country, they began researching mountain tourism earlier (Tables 9 and 10). 
Table 6. Number of citations in 25 countries (from high to low).

\begin{tabular}{cccc}
\hline Country & $\begin{array}{c}\text { Developing/Developed } \\
\text { Countries }\end{array}$ & Continent & Number of Citations \\
\hline U.S. & Developed & North America & 1679 \\
Australia & Developed & Oceania & 1159 \\
China. P. R. & Developing & East Asia & 1053 \\
Switzerland & Developed & Central Europe & 1023 \\
Italy & Developed & South Europe & 880 \\
Spain & Developed & South Europe & 830 \\
Canada & Developed & North America & 727 \\
Germany & Developed & Central Europe & 695 \\
U.K. & Developed & West Europe & 638 \\
Austria & Developed & Central Europe & 528 \\
France & Developed & West Europe & 385 \\
Poland & Developing & Central Europe & 374 \\
Sweden & Developed & North Europe & 311 \\
Norway & Developed & North Europe & 251 \\
Turkey & Developing & West Asia & 238 \\
Romania & Developing & South Europe & 223 \\
Nepal & Developing & South Asia & 212 \\
Greece & Developing & South Europe & 195 \\
Serbia & Developing & South Europe & 171 \\
Czech Republic & Developed & Central Europe & 163 \\
India & Developing & South Asia & 152 \\
South Africa & Developing & Africa & 148 \\
Japan & Developed & East Asia & 123 \\
Slovakia & Developed & Central Europe & 106 \\
Slovenia & Developed & South Europe & 78 \\
\hline & & &
\end{tabular}

Table 7. Number of average citations in 25 countries (from high to low).

\begin{tabular}{cccc}
\hline Country & $\begin{array}{c}\text { Developing/Developed } \\
\text { Countries }\end{array}$ & Continent & Average Citation \\
\hline Switzerland & Developed & Central Europe & 15.9844 \\
Canada & Developed & North America & 15.8043 \\
Australia & Developed & Oceania & 15.4533 \\
U.K. & Developed & West Europe & 13.5745 \\
Nepal & Developing & South Asia & 13.25 \\
U.S. & Developed & North America & 12.5299 \\
Spain & Developed & South Europe & 12.029 \\
Germany & Developed & Central Europe & 11.2097 \\
Sweden & Developed & North Europe & 11.1071 \\
Norway & Developed & North Europe & 9.6538 \\
Italy & Developed & South Europe & 9.4624 \\
Austria & Developed & Central Europe & 8.8 \\
Greece & Developing & South Europe & 8.4783 \\
India & Developing & South Asia & 7.6 \\
South Africa & Developing & Africa & 7.4 \\
Turkey & Developing & West Asia & 6.4324 \\
Japan & Developed & East Asia & 5.8571 \\
Poland & Developing & Central Europe & 5.8438 \\
France & Developed & West Europe & 5.5797 \\
Serbia & Developing & South Europe & 5.0294 \\
Czech Republic & Developed & Central Europe & 4.9394 \\
Slovenia & Developed & South Europe & 4.3333 \\
China. P. R. & Developing & East Asia & 3.4983 \\
Slovakia & Developed & Central Europe & 2.1633 \\
Romania & Developing & South Europe & 2.1442 \\
\hline
\end{tabular}


Table 8. Number of average normalized citations in 25 countries (from high to low).

\begin{tabular}{cccc}
\hline Country & $\begin{array}{c}\text { Developing/Developed } \\
\text { Countries }\end{array}$ & Continent & Avg. Norm. Citation \\
\hline Sweden & Developed & North Europe & 1.9165 \\
Canada & Developed & North America & 1.8586 \\
Australia & Developed & Oceania & 1.8459 \\
Nepal & Developing & South Asia & 1.8222 \\
Switzerland & Developed & Central Europe & 1.7745 \\
Spain & Developed & South Europe & 1.7285 \\
Austria & Developed & Central Europe & 1.6975 \\
Germany & Developed & Central Europe & 1.6811 \\
U.K. & Developed & West Europe & 1.5597 \\
India & Developing & South Asia & 1.5229 \\
Italy & Developed & South Europe & 1.4907 \\
U.S. & Developed & North America & 1.4868 \\
Greece & Developing & South Europe & 1.1594 \\
Norway & Developed & North Europe & 1.1237 \\
South Africa & Developing & Africa & 1.1019 \\
Poland & Developing & Central Europe & 0.9918 \\
France & Developed & West Europe & 0.9739 \\
Slovenia & Developed & South Europe & 0.9076 \\
Turkey & Developing & West Asia & 0.8991 \\
Serbia & Developing & South Europe & 0.8241 \\
Czech Republic & Developed & Central Europe & 0.6498 \\
Japan & Developed & East Asia & 0.6044 \\
China. P. R. & Developing & East Asia & 0.5785 \\
Romania & Developing & South Europe & 0.4353 \\
Slovakia & Developed & Central Europe & 0.3753 \\
\hline
\end{tabular}

Table 9. Top 10 countries' (from early to late) average publication dates (years) from 2010 to 2020.

\begin{tabular}{cccc}
\hline Country & $\begin{array}{c}\text { Developing/Developed } \\
\text { Countries }\end{array}$ & Continent & $\begin{array}{c}\text { Average Publication } \\
\text { Year }\end{array}$ \\
\hline Slovenia & Developed & South Europe & 2013.8333 \\
Turkey & Developing & West Asia & 2014.0541 \\
Nepal & Developing & South Asia & 2014.4667 \\
Switzerland & Developed & Central Europe & 2014.875 \\
Romania & Developing & South Europe & 2015.0192 \\
U.S. & Developed & North America & 2015.0985 \\
Norway & Developed & North Europe & 2015.2174 \\
Czech Republic & Developed & Central Europe & 2015.2812 \\
Australia & Developed & Oceania & 2015.3288 \\
Canada & Developed & North America & 2015.3913 \\
\hline
\end{tabular}

Table 10. Top 10 countries' (from late to early) average publication dates (years) from 2010 to 2020.

\begin{tabular}{cccc}
\hline Country & $\begin{array}{c}\text { Developing/Developed } \\
\text { Countries }\end{array}$ & Continent & $\begin{array}{c}\text { Average Publication } \\
\text { Year }\end{array}$ \\
\hline Poland & Developing & Central Europe & 2016.5968 \\
India & Developing & South Asia & 2016.5789 \\
Austria & Developed & Central Europe & 2016.4833 \\
Sweden & Developed & North Europe & 2016.4815 \\
France & Developed & West Europe & 2016.4638 \\
Spain & Developed & South Europe & 2016.1014 \\
Italy & Developed & South Europe & 2015.9565 \\
Japan & Developed & East Asia & 2015.9 \\
Greece & Developing & South Europe & 2015.7727 \\
Germany & Developed & Central Europe & 2015.7258 \\
\hline
\end{tabular}


The comprehensive analysis of the multiple quantitative measurements, as shown in Table 5, suggested a potential correlation between a country's academic publication and the factors affecting mountain tourism. These influencing factors included but were not limited to mountain tourism resources [77], mountain tourism transportation [21], market factors [78], and population density [75]. These factors may have promoted academic research in several publications in some developing countries, such as those in China and Nepal. However, there is limited evidence for a causal relationship between these influencing factors and the academic achievements of a specific country or region. Further research is needed to analyze the relationship between a country's influencing factors on mountain tourism development and its academic achievements.

\section{Discussion}

The keyword analysis revealed that the emerging research topics in mountain tourism are climate change, sustainable development, sustainability, sustainable tourism, protected areas, rural tourism, and conservation, and that China, the U.S., and Romania produced the most significant mountain tourism articles indexed in the WoS. Most developed countries in Europe had the highest average and average normalized citations, which indicated that they may have more influence in this field of research as compared to other countries. Some developing countries, such as India, Nepal, and China, had higher citations, average citations, and/or average normalized citations than other countries. We also identified several critical research topics in the context of mountain tourism, which we will now discuss, such as research on transport as well as coopetition (i.e., combing with cooperation and competition) in mountain tourism areas.

\subsection{Transport to the Mountain and Economic Efficiency}

Along with climate change, transport is another critical aspect in the sustainable development of mountain tourism. Despite its importance, it did not emerge as a common keyword in our results, and this thus signals the need for further research. No sustainable policy can be designed without sufficient research and investment in transport solutions in mountainous areas. In order to promote the development of comprehensive policies and agendas for sustainable mountain tourism, transport is an essential element [111].

Accessibility and mobility play important roles in regional development strategies that aim to improve the leisure potential of mountainous areas [112]. Tian et al. (2021) took Lijiang as a case study and found that transportation connections constituted the main elements of mountain tourism destinations, and they provided a scientific basis for resource optimization and sustainable development [113]. Paunović and Jovanović's (2019) research in a case study of the German Alps showed that sustainability was dependent on the balance among ecological, social, and economic interests [20]. Poponi et al. (2020) suggested that the Italian national parks of the Apennines and the available transportation options were critical areas for sustainable development, social cultural awareness of conservation issues, and local low-impact economic practices [114].

Transportation impacts the mountainous ecological environment. Juan et al. (2014) suggested that South Tyrol had provided a transportation system that was able to foster tourism in remote and environmentally fragile areas by promoting the usage of public transportation and thus reducing negative impacts caused by the use of private cars [112]. Transportation is one of the main emission sources in mountainous regions [115]; thus, public transportation can better support sustainable tourism as compared to private automobiles. Unger and et al. (2016) focused on developing a model for Alpine tourism and transportation by calculating energy consumption and greenhouse gas emissions resulting from travel to a single Alpine holiday destination [111].

Transportation systems can be used by the local population as well as by tourists to reach recreational activities [112]. However, transportation systems have also presented challenges in their implementation, including increased air pollution and congestion as well as having a negative impact on agricultural and local cultural concerns (e.g., bimodal 
seasonal distribution and a decrease in residents' quality of life) [112]. Despite these obstacles, efficient and sustainable transportation systems can increase accessibility and attract more tourists as well as benefit the residents at a mountain tourism destination. Social and legal bases for high-quality tourism, nature protection, traditional knowledge preservation, and the promotion of environmental education and the culture of local people and visitors can be enhanced by sustainable transportation development in mountain tourism destinations $[116,117]$.

Transportation infrastructure is required in areas that rely on tourism for a significant portion of their local economy, so it is crucial to provide efficient and preferred tourist transportation options, such as cableways in mountainous areas [112]. However, this type of transportation in the Italian Alps has been regarded as relatively economically inefficient, and most of the cableways have reported decreasing returns to scale [112]. The acknowledged negative impact of traffic on the tourism economy has been perceived as less problematic than the potential effects of traffic management [112]. Scuttari and et al. (2019) found that, in the case of the Dolomites, this meant that alternative transportation had to be inexpensive, integrated, and frequently available on an extended daily schedule, whereas any restrictions on private mobility should be clear and limited only to those that were unavoidable [21]. Thus, in ecologically sensitive but tourism-intensive areas, transportation policymakers must contend with the paradox of minimizing transportationrelated impacts while increasing transportation options for tourists [21]. From an economic perspective, it is important to determine whether an alternative and more sustainable mode of transportation will also be economically efficient [112].

\subsection{Romania Created a Competitive Advantage Based on Mountain Tourism}

As shown in Table 5, Romania ranked in the top three productive countries within the context of mountain tourism. Although it has not had much impact on international tourism, this may be changing, as Romania has recently become a favored destination for more tourists due to its natural appeal [118]. Situated in the heart of Europe, Romania is a country with broad tourism potential [119]. Mountainous areas represent approximately $30 \%$ of the territory and are the least anthropically modified, with a low density of stable population and small localities [2]. Romania has a unique heritage, which may give it certain advantages over other countries. Among all the forms of tourism implemented in Romania, mountain tourism has become a priority in terms of availability, accessibility, and diversity as well as the degree of environmental conservation [118].

Romania has a competitive advantage in mountain tourism for several reasons. First, investment programs and initiatives have been focused on the development of mountain tourism, including improving the quality of tourist attractions and facilities [118]. Investors and developers of tourism destinations focus on modernizing existing historical and cultural facilities for accommodation as well as building new facilities that are energy efficient and optimized for their purpose, thereby improving the delivery and quality of the services provided. When formulating investment strategies to improve the efficiency of mountain tourism, they combine public participation and needs, such as infrastructure, accommodation, catering, tourist leisure activities, and mountain sports options, so they can benefit both the residential and the tourist populations. They have participation and support from various entities, such as financial support from local and national governments, the possibility of attracting investment funds through EU plans, and financial support for activities in the mountain tourism sector [118]. The developed tourist resorts were preferred for investment programs financed by the state budget and by European funds [119].

Second, for the investment programs focused on protecting the natural environment, the government played a key role in making decisions and implementing development projects in Romania [119], as well as implementing strategies and policies to protect the natural environment [118]. Administrative agencies for the conservation of natural resources and the protection of cultural and environmental heritage as well as government policies 
ensure the necessary framework is in place to protect the material and natural resources of the area [119].

Since the 2000s, when the Romanian economy experienced a revitalization, a series of studies and projects have been conducted to determine whether a new ski infrastructure or the modernization of the existing one would be more beneficial for the country [119]. Local, national, and even international support as well as targeted research to guide the development of mountain tourism in Romania gives it a competitive advantage [13].

\subsection{Coopetition in Mountain Tourism}

Coopetition is a behavior that generates a network relationship where cooperation and competition coexist [120]. When this relationship occurs among a network of companies or in the economic sector and is nurtured as a continuous process, the result creates a system [120]. Within the context of tourism, coopetition is not a new term [121]; consider Chim-Miki and Batista-Canino's research in the review of tourism coopetition and their research model development [120,122]. Schnitzer et al. (2019) took the Leisure Card Tirol as a case study and analyzed the coopetition between tourism and leisure suppliers [121]. While there has been some research concerning the competition or cooperation in mountain tourism [19], scarce research has been completed regarding coopetition within the context of mountain tourism. The keyword "coopetition" was not shown in the mountain tourism research literature in Figure 3, indicating a need for further study in this area.

First, according to Paunović and Jovanovićs research, cross-border identities have been an important consideration for cross-border cooperation. The most important element in this type of cooperation has been for the destinations to find a common theme (e.g., climate change, demographic change, culture, accessibility, tourism in the public media discourse), share their experiences, and learn from the experiences of the other destinations [19]. However, the challenge has been to adapt tourism policies to create cross-border opportunities that emphasize cultural and historical overlaps among the cross-border regions [19]. For example, a tourist from the U.S. or China may not differentiate between Bavaria, Southeast Bavaria, or Austria.

Second, achieving competitiveness without sustaining it is not a goal worth pursuing [19]. In the case of tourism, competition has proven to be a successful strategy for improving the performance of tourism firms and destination management organizations $[123,124]$. Although competition is a vital concept in the sustainable tourism development research domain [125], competitiveness can be further improved by collaboration and competition [126]. Tourism destinations will have to be sustainable and adhere to the principles of sustainability as well as resilient in their crisis management plans in order to remain competitive in the global market [19].

Third, the coopetition paradigm postulates that corporations not only compete against or cooperate with each other, but can do both at the same time, even in the tourism industry [121]. The coopetition-related research in sustainable tourism was related to the following: (1) Coopetition and sustainable competitive advantage in tourist destinations [123,124,127]; (2) The coopetition model in ecotourism ecosystems [128]; (3) The coopetition between tourism and leisure suppliers [121]; (4) Rural tourism partnership and sustainability [129]; and (5) Coopetition in maritime tourist sustainability [126]. Based on the sustainable principles of mountain tourism, especially those concerning ecological and cultural resources, excessive competition may negatively result in fewer benefits and unreasonable pricing, whereas excessive cooperation may negatively result in a lack of distinct local and cultural identities. Therefore, balancing the relationship between cooperation and competition, also known as coopetition, is also vital for sustainable mountain tourism.

\section{Conclusions}

\subsection{Theoretical Implications}

This study was conducted using classical bibliometric laws and scientometric techniques (VOSViewer) to determine values for production, impact, and relationship. Through 
the analysis of publication years and journals, it was found that the amount of research on mountain tourism has increased. Regarding the scope of research, countries with large mountainous areas, such as the U.S., China, Canada, Australia, Romania, and certain archipelagic countries (e.g., Japan), have researched mountain tourism, and this was especially so in developing countries including Nepal and South Africa. More developed countries in Europe had higher average citations and higher average normalized citations, which indicated the importance of their research in mountain tourism. Regarding research trends in sustainable research in mountain tourism, the national government and other departments have accelerated the network popularization of mountain tourism regions, balanced the relationship between competition and cooperation, and built a coopetition system to promote sustainable global mountain tourism development research, especially in light of the COVID-19 pandemic. As a key piece of research in the area of mountain tourism, Paunović and Jovanović's study integrated knowledge from sustainability and management science with tourism geography and social psychology. They employed a similar research question concerning more sustainable mountain destinations in the German Alps and offered valuable policy implications on which our research was built. Their findings contributed to the understanding of both "threats pushing the agenda of sustainable development (e.g., climate change and depletion of resources), indicators of sustainable tourism (to measure the scope of change)", and "cross-border cooperation and stakeholder engagement" $[19,20]$.

\subsection{Policy Implications}

International coordination is necessary to sustain mountain tourism as a savior of the tourism industry during a global pandemic. The issue of sustainability involves many stakeholders who can combine their knowledge, competencies, and activities to maximize the attractiveness of a location while preserving its resources for the future [130]. Moreover, leadership, intersectoral networks, a standard orientation towards high-quality and sustainable knowledge, energy recycling, and effective communication appear to be critical success factors in mountain tourism development [62]. Some indications of heightened ecological consciousness and a sense of place can be detected among local tourism stakeholders, providing insight for more sustainable mountain tourism development [68].

Alternative sustainable transportation is an important part of mountain tourism for governments and stakeholders [19]. Proper international and cross-border coopetition relationships between destination management organizations contribute to the maximum use of economic, environmental, and social values [20]. There are five key processes, exploiting, exploring, bridging, sharing, and boundary-spanning [131], and seven factors, co-location, associationism, competition, cooperation, strategic management, co-entrepreneurship, and co-production [122]. Planning for crisis management and adhering to the principles of sustainability are two tracks of governance, such as risk management for COVID-19, climate change, and other safety hazards and risks.

Dornier and Mauri (2018) indicated that sustainability in mountain tourism has many facets, and it involves many aspects of tourism management: mobility and mobility infrastructure; global warming, snow shortage, and the long-term viability of ski stations; pollution and clean air; the price of accessibility; stakeholders' involvement and networking; and cross-border partnerships [130]. There were three main issues raised in their study: (1) Increasingly, tourists have preferred to visit mountain destinations that have plenty of natural and healthy resources and are safer than other forms of tourism, especially in light of the continuing COVID-19 pandemic; (2) The increasing popularity of mountain tourism depleted the value of preserving a pristine natural environment; (3) The competitive market failed to allocate resources efficiently to offset these negative externalities.; (4) Economic inefficiency due to market failure required governments to coordinate research in sustainable tourism. 


\subsection{Further Research Direction and Limitations}

Future directions for research could include: (1) How the international organizations mobilize industry resources, support innovation and technology, and cultivate coopetition models for the tourism market to allocate resources efficiently; (2) as per other field of research, such as construction safety [132,133], government operations [134], artificial intelligence solutions. As such it may enhance transport and/or coopetition between sustainable mountain tourism destinations and shall become one new research area; (3) Likewise, the popularity of various Web 2.0 tools such as LinkedIn and Facebook which allow us to read and write in internet [135] offers a new source of data, similar approach used by Song et al. [136] for Twitter analysis can be adopted; (3) Comparative analyses of science mapping between Google Scholar, WoS, and/or Scopus shall provide a new research angle in the future.Our research had some limitations. (1) This study used 1413 papers from only one database (WoS), which does not represent all of the research papers published globally. Therefore, the conclusion and the method should only be considered within the context of mountain tourism research from this database. Whether our method would be suitable for another research field would need to be studied and confirmed further. (2) According to Paunović and Jovanović's findings, an interpretative, qualitative interview methodology can provide richer data and greater insights into phenomena compared to questionnaires; therefore, the qualitative interview method would increase the strength of our findings in addition to the science mapping analysis; otherwise, some keywords could be overlooked, such as transport, competition, cooperation, etc.

Author Contributions: Conceptualization, L.Z., J.N., Y.M. and J.S.; methodology, L.Z. and R.Y.M.L.; software, L.Z.; validation, L.Z., R.Y.M.L. and Y.M.; formal analysis, L.Z.; investigation, L.Z. and Y.M.; resources, L.Z.; data curation, L.Z.; writing-original draft preparation, L.Z.; writing-review and editing, L.Z. and R.Y.M.L.; visualization, L.Z.; project administration, L.Z. and R.Y.M.L.; funding acquisition, L.Z. All authors have read and agreed to the published version of the manuscript.

Funding: This research was funded by the Ph.D. Starting Research Fund from the Panzhihua University (No. 035200153).

Institutional Review Board Statement: Not applicable.

Informed Consent Statement: Informed consent was obtained from all subjects involved in the study.

Data Availability Statement: Not applicable.

Conflicts of Interest: The authors declare no conflict of interest.

\section{References}

1. Lenart-Boron, A.; Boron, P.; Prajsnar, J.; Guzik, M.; Zelazny, M.; Pufelska, M.; Chmiel, M. COVID-19 lockdown shows how much natural mountain regions are affected by heavy tourism. Sci. Total Environ. 2022, 806, 151355. [CrossRef]

2. Cristache, N.; Soare, I.; Nastase, M.; Antohi, V. Integrated approach of the entrepreneurial behaviour in the tourist sector from disadvantaged mountain areas from Romania. Environ. Dev. Sustain. 2021, 1-17. [CrossRef]

3. Zhang, W. The Enlightenment of Foreign Mountain Tourism Development to China. J. Shanxi Coal Min. Adm. Coll. 2014, $27,3$.

4. Chen, W.M. The stragegy of mountain tourism development in Nepal and its enlightenment for Western China. Tour. Forum 2017, 10,9 .

5. Chen, J.Y. Science mapping approach to assisting the review of construction and T demolition waste management research published between 2009 and 2018. Resour. Conserv. Recycl. 2019, 140, 175-188.

6. Río-Rama, M.; Maldonado-Erazo, C.; Durán-Sánchez, A.; Álvarez-García, J. Mountain Tourism Research. A Review. Eur. J. Tour. Res. 2019, 22, 130-150.

7. Jiang, Z. A Review of Mountain Tourism Environment Research. J. Chongqing Norm. Univ. (Nat. Sci.) 2007, $24,77-81$.

8. Xie, Z. Research progress on land use and cover change of domestic mountain tourism destination. J. Henan Univ. $2015,45,7$.

9. Tian, M. Hotspots, progress and enlightenments of foreign mountain tourism research. World Reg. Stud. 2020, $29,1071-1081$.

10. Körner, S. Mountain Biodiversity—A Global Assessment; Parthenon Publishing: London, UK, 2002.

11. Wang, M. Main fields and suggestions of mountain tourism research. J. Guilin Univ. Technol. 2017, $37,8$.

12. Chen, N.; Zhang, T. Mountain Tourism. In Dictionary of Geotourism; 2020. Available online: https://webvpn.dlut.edu.cn/https/77 726476706e69737468656265737421fcfe4f976923784277068ea98a1b203a54/referenceworkentry/10.1007/978-981-13-2538-0_1640 (accessed on 18 May 2021). 
13. Bacoş, I.B.; Gabor, M.R. Tourism Economy. Mountain Tourism: Quantitative Analysis of Winter Destinations in Romania. Economics 2021, 9, 143-159. [CrossRef]

14. Buning, R.; Lamont, M. Mountain bike tourism economic impacts: A critical analysis of academic and practitioner studies. Tour. Econ. 2021, 27, 500-509. [CrossRef]

15. Zeng, L.; Li, R.; Huang, X. Sustainable Mountain-Based Health and Wellness Tourist Destinations: The Interrelationships between Tourists' Satisfaction, Behavioral Intentions, and Competitiveness. Sustainability 2021, 13, 13314. [CrossRef]

16. Romeo, R.; Grita, F.; Parisi, F.; Russo, L. Vulnerability of Mountain Peoples to Food Insecurity: Updated Data and Analysis of Drivers; FAO and UNCCD: Rome, Italy, 2020. [CrossRef]

17. Immerzeel, W.W.; Lutz, A.F.; Andrade, M.; Bahl, A.; Biemans, H.; Bolch, T.; Hyde, S.; Brumby, S.; Davies, B.J.; Elmore, A.C.; et al. Importance and vulnerability of the world's water towers. Nature 2020, 577, 364-369. [CrossRef]

18. Hock, R.G.; Rasul, C.; Adler, B.C.C.; Gruber, S.; Hirabayashi, Y.; Jackson, M.; Kääb, A.; Kang, S.; Kutuzov, S.; Milner, A.; et al. IPCC Special Report on the Ocean and Cryosphere in a Changing Climate. 2019. Available online: https://www.ipcc.ch/srocc/ (accessed on 15 January 2021).

19. Paunovic, I.; Jovanovic, V. Implementation of Sustainable Tourism in the German Alps: A Case Study. Sustainability 2017, 9, 226. [CrossRef]

20. Paunović, I.; Jovanović, V. Sustainable Mountain Tourism in Word and Deed: A Comparative Analysis in the Macro-Regions of the Alps and the Dinarides. Acta Geogr. Slov. 2019, 59. [CrossRef]

21. Scuttari, A.; Orsi, F.; Bassani, R. Assessing the tourism-traffic paradox in mountain destinations. A stated preference survey on the Dolomites' passes (Italy). J. Sustain. Tour. 2019, 27, 241-257. [CrossRef]

22. Vukoicic, D.; Ivanovic, R.; Radovanovic, D.; Dragojlovic, J.; Martic-Bursac, N.; Ivanovic, M.; Ristic, D. Assessment of Geotourism Values and Ecological Status of Mines in Kopaonik Mountain (Serbia). Minerals 2020, 10, 269. [CrossRef]

23. Shih, N.; Lin, C. The evolving urban fabric and contour of old mountain streets in Taiwan. Tour. Geogr. 2019, 21, 24-53. [CrossRef]

24. Song, J.; Zhang, H.; Dong, W. A review of emerging trends in global PPP research: Analysis and visualization. Scientometrics 2016, 107, 1111-1147. [CrossRef]

25. Aggarwal, A.; Frey, H.; McDowell, G.; Drenkhan, F.; Nusser, M.; Racoviteanu, A.; Hoelzle, M. Adaptation to climate change induced water stress in major glacierized mountain regions. Clim. Dev. 2021, 1-13. [CrossRef]

26. Demiroglu, O.; Hall, C. Geobibliography and Bibliometric Networks of Polar Tourism and Climate Change Research. Atmosphere 2020, 11, 498. [CrossRef]

27. Liu, W.; Yu, H.; Hsieh, C. Evaluating Forest Visitors' Place Attachment, Recreational Activities, and Travel Intentions under Different Climate Scenarios. Forests 2021, 12, 171. [CrossRef]

28. Bonzanigo, L.; Giupponi, C.; Balbi, S. Sustainable tourism planning and climate change adaptation in the Alps: A case study of winter tourism in mountain communities in the Dolomites. J. Sustain. Tour. 2016, 24, 637-652. [CrossRef]

29. Salim, E.; Mabboux, L.; Ravanel, L.; Deline, P.; Gauchon, C. A history of tourism at the Mer de Glace: Adaptations of glacier tourism to glacier fluctuations since 1741. J. Mt. Sci. 2021, 18, 1977-1994. [CrossRef]

30. Dar, R.; Rashid, I.; Romshoo, S.; Marazi, A. Sustainability of winter tourism in a changing climate over Kashmir Himalaya Environ. Monit. Assess. 2014, 186, 2549-2562. [CrossRef]

31. Fort, M. Natural hazards versus climate change and their potential impacts in the dry, northern Himalayas: Focus on the upper Kali Gandaki (Mustang District, Nepal). Environ. Earth Sci. 2015, 73, 801-814. [CrossRef]

32. Zhong, Z.P.; Solonenko, N.E.; Li, Y.F.; Gazitúa, M.C.; Roux, S.; Davis, M.E.; Van Etten, J.L.; Mosley-Thompson, E.; Rich, V.I.; Sullivan, M.B.; et al. Glacier ice archives fifteen-thousand-year-old viruses. BioRxiv 2020. Available online: https://www.biorxiv. org/content/10.1101/2020.01.03.894675v1.abstract (accessed on 24 December 2021).

33. Hoy, A.; Hansel, S.; Matschullat, J. How can winter tourism adapt to climate change in Saxony's mountains? Reg. Environ. Chang. 2011, 11, 459-469. [CrossRef]

34. Probstl-Haider, U.; Hodl, C.; Ginner, K.; Borgwardt, F. Climate change: Impacts on outdoor activities in the summer and shoulder seasons. J. Outdoor Recreat. Tour.-Res. Plan. Manag. 2021, 34, 100344. [CrossRef]

35. Wang, D. Artificial intelligence-based mountain soil erosion and the impact of climate conditions on marathon competitions. Arab. J. Geosci. 2021, 14, 948. [CrossRef]

36. Wang, S.; Qin, D. Mountain inhabitants' perspectives on climate change, and its impacts and adaptation based on temporal and spatial characteristics analysis: A case study of Mt. Yulong Snow, Southeastern Tibetan Plateau. Environ. Hazards-Hum. Policy Dimens. 2015, 14, 122-136. [CrossRef]

37. Vij, S.; Biesbroek, R.; Adler, C.; Muccione, V. Climate Change Adaptation in European Mountain Systems: A Systematic Mapping of Academic Research. Mt. Res. Dev. 2021, 41, A1-A6. [CrossRef]

38. Wolfle, F.; Schnorbus, L.; Klein, A.; Wittmann-Wurzer, A.; Neumann, P.; Oven-Krockhaus, I. Winter Tourism in German Low Mountain Range and Uplands in the Context of Climate Change. Z. Fur Tour. 2018, 10, 303-317. [CrossRef]

39. Ziegler, A.; Wasson, R.; Sundriyal, Y.; Srivastava, P.; Sasges, G. A call for reducing tourism risk to environmental hazards in the Himalaya COMMENT. Environ. Hazards-Hum. Policy Dimens. 2021, 1-28. [CrossRef]

40. Thimm, T.; Bild, C.; Kalff, M. Climate change in low mountain ranges: Opportunities in sustainable Black Forest tourism. Eur. J. Tour. Res. 2019, 23, 63-70. 
41. Willibald, F.; Kotlarski, S.; Ebner, P.; Bavay, M.; Marty, C.; Trentini, F.; Ludwig, R.; Gret-Regamey, A. Vulnerability of ski tourism towards internal climate variability and climate change in the Swiss Alps. Sci. Total Environ. 2021, 784, 147054. [CrossRef]

42. Gabriel-Campos, E.; Werner-Masters, K.; Cordova-Buiza, F.; Paucar-Caceres, A. Community eco-tourism in rural Peru: Resilience and adaptive capacities to the Covid-19 pandemic and climate change. J. Hosp. Tour. Res. 2021, 48, 416-427. [CrossRef]

43. Milicevic, S.; Boskovic, N.; Lakicevic, M. Sustainable tourism development in mountain areas in Sumadija and Western Serbia. J. Mt. Sci. 2021, 18, 735-748. [CrossRef]

44. Dornier, R.; Mauri, C. Conclusions: Managing tourism sustainability in mountain destinations. Worldw. Hosp. Tour. Themes 2018, 10, 267-273. [CrossRef]

45. Wagenseil, Z. Sustainable Tourism in Mountain Destinations: The Perceived and Actual Role of a Destination Management Organization. In Sustainable Mountain Regions: Challenges and Perspectives in Southeastern Europe; Koulov, B., Zhelezov, G., Eds.; Springer: Cham, Switzerland, 2016; Volume 1, p. 10.

46. Singh, M. Green Tourism in Mountain Regions-Reducing Vulnerability and Promoting People and Place Centric Development in the Himalayas. J. Mt. Sci. 2004, 1, 57-64. [CrossRef]

47. Debarbieux, B.; Oiry, V.M.; Rudaz, G.; Maselli, D.; Kohler, T.; Jurek, M. Tourism in Mountain Regions: Hopes, Fears and Realities. Sustainable Mountain Development Series; UNIGE: Geneva, Switzerland; CDE: Geneva, Switzerland; SDC: Geneva, Switzerland, 2014.

48. Demirovic, D.; Radovanovic, M.; Petrovic, M.; Cimbaljevic, M.; Vuksanovic, N.; Vukovic, D. Environmental and Community Stability of a Mountain Destination: An Analysis of Residents' Perception. Sustainability 2018, 10, 70. [CrossRef]

49. Cousquer, G.O. Encyclopedia of Tourism; Springer International Publishing: Geneva, Switzerland, 2014. [CrossRef]

50. Mutana, S.; Mukwada, G. Mountain-route tourism and sustainability. A discourse analysis of literature and possible future research. J. Outdoor Recreat. Tour.-Res. Plan. Manag. 2018, 24, 59-65. [CrossRef]

51. Mutana, S.; Mukwada, G. An Exploratory Assessment of Significant Tourism Sustainability Indicators for a Montane-Based Route in the Drakensberg Mountains. Sustainability 2017, 9, 1202. [CrossRef]

52. Havlikova, M.; Stupkova, L.; Pliskova, L. Evaluation of sustainable tourism potential of the principle Giant Mountains resorts in the Czech Republic. Environ. Socio-Econ. Stud. 2019, 7, 26-35. [CrossRef]

53. Duglio, S.; Bonadonna, A.; Letey, M.; Peira, G.; Zavattaro, L.; Lombardi, G. Tourism Development in Inner Mountain Areas-The Local Stakeholders' Point of View through a Mixed Method Approach. Sustainability 2019, 11, 5997. [CrossRef]

54. Dax, T.; Zhang, D.; Chen, Y. Agritourism Initiatives in the Context of Continuous Out-Migration: Comparative Perspectives for the Alps and Chinese Mountain Regions. Sustainability 2019, 11, 4418. [CrossRef]

55. Podovac, M.; Đorđević, N.; Milićević, S. Rural Tourism in the Function of Life Quality Improvement of Rural Population on Goc Mountain. Ekon. Poljopr.-Econ. Agric. 2019, 66, 205-220. [CrossRef]

56. Kortoci, Y.; Kortoci, M. The assessment of the rural tourism development in the Valbona Valley National Park. Tour. Econ. 2017, 23, 1662-1672. [CrossRef]

57. Linca, A.; Toma, E. Study Regarding the Evolution of Mountain Tourism and Rural Mountain Tourism in the Romanian Carpathians During COVID-19 Pandemic. Sci. Pap.-Ser. Manag. Econ. Eng. Agric. Rural. Dev. 2021, 21, 357-363.

58. Statuto, D.; Picuno, P. Valorisation of vernacular farm buildings for the sustainable development of rural tourism in mountain areas of the Adriatic-Ionian macro-region. J. Agric. Eng. 2017, 48, 21-26. [CrossRef]

59. Khartishvili, L.; Muhar, A.; Dax, T.; Khelashvili, I. Rural Tourism in Georgia in Transition: Challenges for Regional Sustainability. Sustainability 2021, 11, 410. [CrossRef]

60. Savulescu, I.; Mihai, B.; Virghileanu, M.; Nistor, C.; Olariu, B. Mountain Arable Land Abandonment (1968-2018) in the Romanian Carpathians: Environmental Conflicts and Sustainability Issues. Sustainability 2019, 11, 6679. [CrossRef]

61. Maksimović, M.; Janovac, T.; Karabašević, D.; Brzaković, M. Solution of General and Prevention of Ecological Problems of Stara Planina Mountain as Potential Obstacles to the Development of Rural Tourism. Ekon. Poljopr.-Econ. Agric. 2018, 65, 531-544. [CrossRef]

62. Lun, L.; Pechlaner, H.; Volgger, M. Rural Tourism Development in Mountain Regions: Identifying Success Factors, Challenges and Potentials. J. Qual. Assur. Hosp. Tour. 2016, 17, 389-411. [CrossRef]

63. Lulcheva, I. Opportunities for the Development of Rural Tourism in Small Settlements. Sci. Pap.-Ser. Manag. Econ. Eng. Agric. Rural. Dev. 2018, 18, 283-288.

64. Abellan, F.; Martinez, C. Landscape and Tourism as Tools for Local Development in Mid-Mountain Rural Areas in the Southeast of Spain (Castilla-La Mancha). Land 2021, 10, 221. [CrossRef]

65. Nepal, S.K.; Chipeniuk, R. Mountain tourism: Toward a conceptual framework. Tour. Geogr. 2005, 7, 313-333. [CrossRef]

66. Vespestad, M.K.; Lindberg, F. Understanding nature-based tourist experiences: An ontological analysis. Current Issues in Tourism 2011, 14, 563-580. [CrossRef]

67. Duozi, L. On development of tourist programs in mountainous attractions. Shaixi Archit. 2018, 44, 3.

68. Chakraborty, A. Japan's Mountain Tourism at a Crossroads: Insights from the North Japan Alps. Tour. Plan. Dev. 2018, 15, 82-88. [CrossRef]

69. Zheng, N. Automatic Early Warning Method for Landscape Tourism Ecological Environment Pollution of Mountain Scenic Spot. Ekoloji 2019, 28, 2917-2928. 
70. Dimitrov, N.; Markoski, B.; Petrevska, B.; Koteski, C. Mountain Tourism in Mecedonia: Assessment of the National Park "Pelister". In Proceedings of the 3rd International Scientific Conference on Geobalcanica, Skopje, North Macedonia, 20-21 May 2017; pp. 225-232.

71. Wang, J.; Liu, H.; Ming, Q. The Composition of Mountain Tourism Attractiveness in Coastal Provinces: Case Study of Guangxi. J. Coast. Res. 2020, 103, 1153-1157. [CrossRef]

72. Nevistic, Z.; Spoljaric, D. Web GIS in mountaineering in Croatia. Geoscape 2019, 13, 114-124. [CrossRef]

73. Hu, B.; Tuou, Y.; Liu, J. How Does Destination Social Responsibility Impact Residents' Pro-Tourism Behaviors? The Mediating Role of Place Attachment. Sustainability 2019, 11, 3373. [CrossRef]

74. Jiang, H.; Yang, Y.; Bai, Y. Evaluation of All-for-One Tourism in Mountain Areas Using Multi-Source Data. Sustainability 2018, 10, 4065. [CrossRef]

75. Telbisz, T.; Brankov, J.; Calic, J. Topographic and lithologic controls behind mountain depopulation in Zlatibor District (Western Serbia). J. Mt. Sci. 2020, 17, 271-288. [CrossRef]

76. Li, S.; Li, X. The development of the zhongnan mountain cultural tourism based on the analysis of SWOT. Agro Food Ind. Hi-Tech 2017, 28, 1265-1269.

77. Gu, Y. Evaluation of Agricultural Cultural Heritage Tourism Resources Based on Grounded Theory on Example of Ancient Torreya Grandis In Kuaiji Mountain. J. Environ. Prot. Ecol. 2018, 19, 1193-1199.

78. Taczanowska, K.; González, L.M.; García-Massó, X.; Zięba, A.; Brandenburg, C.; Muhar, A.; Pellicer-Chenoll, M.; Toca-Herrera, J.L. Nature-based Tourism or Mass Tourism in Nature? Segmentation of Mountain Protected Area Visitors Using Self-Organizing Maps (SOM). Sustainability 2019, 11, 1314. [CrossRef]

79. Apollo, M.; Andreychouk, V. Trampling Intensity and Vegetation Response and Recovery according to Altitude: An Experimental Study from the Himalayan Miyar Valley. Resources 2020, 9, 98. [CrossRef]

80. Kabil, M.; Priatmoko, S.; Magda, R.; David, L. Blue Economy and Coastal Tourism: A Comprehensive Visualization Bibliometric Analysis. Sustainability 2021, 13, 3650. [CrossRef]

81. Ruiz-Real, J.; Uribe-Toril, J.; Valenciano, J.; Gazquez-Abad, J. Rural tourism and development: Evolution in Scientific Literature and Trends. J. Hosp. Tour. Res. 2020, 20, 1-25. [CrossRef]

82. Shasha, Z.; Geng, Y.; Sun, H.; Musakwa, W.; Sun, L. Past, current, and future perspectives on eco-tourism: A bibliometric review between 2001 and 2018. Environ. Sci. Pollut. Res. 2020, 27, 23514-23528. [CrossRef]

83. Hall, C.M. The Impact of Tourism Knowledge: Google Scholar, citations and the opening up of academic space. E-Rev. Tour. Res. 2006, 4, 119-136.

84. Li, K.; Rollins, J.; Yan, E. Web of Science use in published research and review papers 1997-2017: A selective, dynamic, crossdomain, content-based analysis. Scientometrics 2018, 115, 1-20. [CrossRef]

85. Li, J.; Weng, G.; Pan, Y.; Li, C.; Wang, N. A scientometric review of tourism carrying capacity research: Cooperation, hotspots, and prospect. J. Clean. Prod. 2021, 325, 129278. [CrossRef]

86. Vega-Munoz, A.; Arjona-Fuentes, J.; Ariza-Montes, A.; Han, H.; Law, R. In search of 'a research front' in cruise tourism studies. Int. J. Hosp. Manag. 2020, 85, 102353. [CrossRef]

87. Madrid-Casaca, H.; Salazar-Sepulveda, G.; Contreras-Barraza, N.; Gil-Marin, M.; Vega-Munoz, A. Global Trends in Coffee Agronomy Research. Agronomy 2021, 11, 1471. [CrossRef]

88. Price, D. General Theory of Bibliometric And Other Cumulative Advantage Processes. J. Am. Soc. Inf. Sci. 1976, 27, 292-306. [CrossRef]

89. Acevedo-Duque, A.; Vega-Munoz, A.; Salazar-Sepulveda, G. Analysis of Hospitality, Leisure, and Tourism Studies in Chile. Sustainability 2020, 12, 7238. [CrossRef]

90. Bulick, S. Book Use As A Bradford-Zipf Phenomenon. Coll. Res. Libr. 1978, 39, 215-219. [CrossRef]

91. Pontigo, J.; Lancaster, F. Qualitative Aspects of the Bradford Distribution. Scientometrics 1986, 9, 59-70. [CrossRef]

92. Kumar, S. Application of Bradford's Law to Human-Computer Interaction Research Literature. Desidoc J. Libr. Inf. Technol. 2014, 34, 223-231.

93. Shelton, R.D. Scientometric laws connecting publication counts to national research funding. Scientometrics 2020, 123, 181-206. [CrossRef]

94. Zipf, G.K. Selected Studies of the Principle of Relative Frequency in Language; Harvard University Press: Cambridge, MA, USA, 1932.

95. Vega-Munoz, A.; Gonzalez-Gomez-del-Mino, P.; Espinosa-Cristia, J. Recognizing New Trends in Brain Drain Studies in the Framework of Global Sustainability. Sustainability 2021, 13, 3195. [CrossRef]

96. Deng, Y.C.; Chang, J.; Zhuo, X. China in the past two decades Overview of foreign TOD research progress-based on Cite Space Visualization analysis of software. Res. Mod. Cities 2019, 2, 94-100. Available online: https://webvpn.dlut.edu.cn/https/7772 6476706e69737468656265737421fcfe4f976923784277068ea98a1b203a54/chapter/10.1007/978-3-319-10377-8_13 (accessed on 20 December 2021). (In Chinese)

97. Cassettari, R.; Pinto, A.; Rodrigues, R.; Leticia-Silvana-dos Santos. Comparison of Zipf's law in textual content and oral discourse. Prof. De La Inf. 2015, 24, 157-167. [CrossRef]

98. Coile, R. Lotkas Frequency-Distribution of Scientific Productivity. J. Am. Soc. Inf. Sci. 1977, 28, 366-370. [CrossRef]

99. Du, G.; Huang, L.; Zhou, M. Variance Analysis and Handling of Clinical Pathway: An Overview of the State of Knowledge. IEEE Access 2020, 8, 158208-158223. [CrossRef] 
100. Lotka, A.J. The frequency distribution of scientific productivity. J. Wash. Acad. Sci. 1926, 16, 317-323.

101. Koseoglu, M.; Okumus, F.; Putra, E.; Yildiz, M.; Dogan, I. Authorship Trends, Collaboration Patterns, and Co-Authorship Networks in Lodging Studies (1990-2016). J. Hosp. Mark. Manag. 2018, 27, 561-582. [CrossRef]

102. Lojo, A.; Li, M.; Canoves, G. Co-authorship Networks and Thematic Development in Chinese Outbound Tourism Research. J. China Tour. Res. 2019, 15, 295-319. [CrossRef]

103. Van Eck, N.J.; Waltman, L. Visualizing bibliometric networks. In Measuring Scholarly Impact: Methods and Practice; Ding, Y., Rousseau, R., Wolfram, D., Eds.; Springer: Cham, Switzerland, 2014; pp. 285-320.

104. He, X.R.; Huang, C.H.; Yang, K. Research Progress of Healthy Urban Planning Based on CiteSpace at China and Out of China. Chin. Overseas Archit. 2020, 13, 121-125. (In Chinese)

105. Su, H.N.; Lee, P.C. Mapping knowledge structure by keyword co-occurrence: A first look at journal papers in Technology Foresight. Scientometrics 2010, 85, 65-79. [CrossRef]

106. Cheng, F.-F.; Huang, Y.-W.; Yu, H.-C.; Wu, C.-S. Mapping knowledge structure by keyword co-occurrence and social network analysis. Libr. Hi Tech 2018, 36, 636-650. [CrossRef]

107. Rixen, C.; Teich, M.; Lardelli, C.; Gallati, D.; Pohl, M.; Putz, M.; Bebi, P. Winter Tourism and Climate Change in the Alps: An Assessment of Resource Consumption, Snow Reliability, and Future Snowmaking Potential. Mt. Res. Dev. 2011, 31, 229-236. [CrossRef]

108. Beniston, M. Impacts of climatic change on water and associated economic activities in the Swiss Alps. Ournal Hydrol. 2012, 412, 291-296. [CrossRef]

109. Pickering, C.M.; Hill, W.; Newsome, D.; Leung, Y.F. Comparing hiking, mountain biking and horse riding impacts on vegetation and soils in Australia and the United States of America. J. Environ. Manag. 2010, 91, 551-562. [CrossRef]

110. Barros, A.; Gonnet, J.; Pickering, C. Impacts of informal trails on vegetation and soils in the highest protected area in the Southern Hemisphere. J. Environ. Manag. 2013, 127, 50-60. [CrossRef]

111. Unger, R.; Abegg, B.; Mailer, M.; Stampfl, P. Energy Consumption and Greenhouse Gas Emissions Resulting From Tourism Travel in an Alpine Setting. Mt. Res. Dev. 2016, 36, 475-483. [CrossRef]

112. Juan, G.B.; Manuela, D.; Manuela, P. Tourism and transport systems in mountain environments: Analysis of the economic efficiency of cableways in South Tyrol. J. Transp. Geogr. 2014, 36, 1-11. [CrossRef]

113. Tian, J.; Ming, Q. Spatial Connection Between Mountainous Scenic Spot and Town in Mountain Tourism Destination and Coupling Mechanism: A Cases Study From Lijiang, Yunnan. Econ. Geogr. 2021, 41, 212-220.

114. Poponi, S.; Palli, J.; Ferrari, S.; Filibeck, G.; Forte, T.; Franceschini, C.; Ruggieri, A.; Piovesan, G. Toward the development of sustainable ecotourism in Italian national parks of the Apennines: Insights from hiking guides. Ecol. Soc. 2020, 25, 46. [CrossRef]

115. Xiang, X.; Dong, Y.; Yang, X. Estimation and Analysis of Carbon Source and Carbon Sink of Mountain Scenic Spots A Case Study of Xiling Snow Mountain. J. Southwest Univ. Nat. Sci. Ed. 2014, 36, 150-159.

116. Kipkeeva, P.A.; Potapenko, Y.Y. Principal factors of sustainable tourism in the Karachai-Cherkess Republic. Vestn. Mosk. Universiteta. Seriya 5 Geogr. 2015, 5, 76-81.

117. Thorn, J.; Klein, J.; Steger, C.; Hopping, K.; Capitani, C.; Tucker, C.; Reid, R.; Marchant, R. Scenario archetypes reveal risks and opportunities for global mountain futures. Glob. Environ. Chang.-Hum. Policy Dimens. 2021, 69, 102291. [CrossRef]

118. Emanoil, S.A.V.I.N. Strategies to increase economic efficiency through investment activities in mountain tourism. In Proceedings of the The Ninth International Conference "Investments and Economic Recovery", Bucharest, Romania, 22-23 May 2009; pp. 91-95.

119. Cernaianu, S.; Sobry, C. The Development of Ski Areas in Romania. What Environmental, Political, and Economic Logic? Sustainability 2021, 13, 274. [CrossRef]

120. Chim-Miki, A.; Batista-Canino, R. Tourism coopetition: An introduction to the subject and a research agenda. Int. Bus. Rev. 2017, 26, 1208-1217. [CrossRef]

121. Schnitzer, M.; Seidl, M.; Schlemmer, P.; Peters, M. Analyzing the Coopetition between Tourism and Leisure Suppliers-A Case Study of the Leisure Card Tirol. Sustainability 2018, 10, 1447. [CrossRef]

122. Chim-Miki, A.; Batista-Canino, R. Development of a tourism coopetition model: A preliminary Delphi study. J. Hosp. Tour. Manag. 2018, 37, 78-88. [CrossRef]

123. Della Corte, V.; Aria, M. Coopetition and sustainable competitive advantage. The case of tourist destinations. Tour. Manag. 2016, 54, 524-540. [CrossRef]

124. Kylanen, M.; Mariani, M.M. Unpacking the temporal dimension of coopetition in tourism destinations: Evidence from Finnish and Italian theme parks. Anatolia 2012, 23, 61-74. [CrossRef]

125. Grauslund, D.; Hammershoy, A. Patterns of network coopetition in a merged tourism destination. Scand. J. Hosp. Tour. 2021, 21, 192-211. [CrossRef]

126. Lam-Gonzalez, Y.; Leon, C.; de Leon, J. Coopetition in Maritime Tourism: Assessing the Effect of Previous Islands' Choice and Experience in Tourist Satisfaction. Sustainability 2019, 11, 6334. [CrossRef]

127. Crick, J.M.; Crick, D. The dark-side of coopetition: Influences on the paradoxical forces of cooperativeness and competitiveness across product-market strategies. J. Bussiness Res. 2021, 122, 226-240. [CrossRef]

128. Salvado, J.O.M.G. Enotourism ecosystem: Stakeholders' coopetition model proposal. Tour. Hosp. Int. J. 2016,6 , 77-93.

129. Pilving, T.; Kull, T.; Suskevics, M.; Viira, A. The tourism partnership life cycle in Estonia: Striving towards sustainable multisectoral rural tourism collaboration. Tour. Manag. Perspect. 2019, 31, 219-230. [CrossRef] 
130. Dornier, R.; Mauri, C. Overview: Tourism sustainability in the Alpine region: The major trends and challenges. Worldw. Hosp. Tour. Themes 2018, 10, 136-139. [CrossRef]

131. Fong, V.; Wong, I.; Hong, J. Developing institutional logics in the tourism industry through coopetition. Tour. Manag. 2018, 66, 244-262. [CrossRef]

132. Li, R.Y.M. An Economic Analysis on Automated Construction Safety: Internet of Things, Artificial Intelligence and 3D Printing; Springer: Singapore, 2017; pp. 1-173.

133. Luo, F.; Li, R.Y.M.; Crabbe, M.J.C.; Pu, R. Economic development and construction safety research: A bibliometrics approach. Saf. Sci. 2022, 145, 105519. [CrossRef]

134. Yigitcanlar, T.; Corchado, J.M.; Mehmood, R.; Li, R.Y.M.; Mossberger, K.; Desouza, K. Responsible Urban Innovation with Local Government Artificial Intelligence (AI): A Conceptual Framework and Research Agenda. J. Open Innov. Tech. Market Complex. 2021, 7, 71. [CrossRef]

135. Li, R.Y.M.; Poon, S.W. Using Web 2.0 to share knowledge of construction safety: The fable of economic animals. Econ. Aff. 2011, 31, 73-79. [CrossRef]

136. Song, L.; Li, R.Y.M.; Yao, Q. An informal institution comparative study of occupational safety knowledge sharing via French and English Tweets: Languaculture, weak-strong ties and AI sentiment perspectives. Saf. Sci. 2022, 147, 105602. [CrossRef] 